\title{
Brittleness of gas shale reservoirs: a case study from the North Perth basin, Australia
}

\author{
Raoof Gholami ${ }^{1}$, Vamegh Rasouli ${ }^{2}$, Mohammad Sarmadivaleh ${ }^{3}$, Vida Minaeian ${ }^{3}$, Nikoo Fakhari ${ }^{4}$ \\ 1- Department of Petroleum Engineering, Curtin University, Malaysia \\ E-mail: Raoof.Gholami@Curtin.edu.my \\ 2- Department of Petroleum Engineering, University of North Dakota, USA \\ 3- Department of Petroleum Engineering, Curtin University, Australia \\ 3- Department of Chemistry, Shahrood University of Technology, Iran
}

\begin{abstract}
Shale reservoirs have gained the attention of many in recent years due to their potential as a major gas resource. Production from this kind of formation, however, requires an accurate estimation of brittleness and employments of hydraulic fracturing. There have been many studies as to how brittleness can be estimated, but few research works were carried out so far indicating how brittleness indices vary in gas shale formations. The aim of this paper is to evaluate the variation of brittleness in one of the gas shale reservoirs located in the north Perth Basin of Australia. The results obtained indicated that the lower part of the Carynginia shale should be selected for a hydraulic fracturing job due to a high brittleness index, although a careful analysis of Total Organic Content (TOC) might be required before initiating any plans. The mineralogical report and interpretations revealed that the space created by cross-plotting the elastic parameters is able to identify dominant minerals contributing into brittleness. Performing a series of true triaxial tests, which are capable of simulating the real field condition by applying three independent principal stresses, implied that as the stress anisotropy increases, a transition takes place from brittle towards the ductile behaviours. However, when this anisotropy becomes significant, samples regain their strength. This study, therefore, recommends more studies to get a practical conclusion on brittleness under true triaxial conditions.
\end{abstract}

Keywords: Shale gas reservoirs, anisotropy, North Perth basin, water saturation, true triaxial tests

\section{Introduction}

Development of tight oil and gas reservoirs has been an outstanding challenge in the past decade. Shale has been fractured and used for gas and oil productions for many years in the U.S. (Selley, 2012). It has also been the topic of interest for oil and gas companies located in Australia, Canada, Asia and Europe. This is perhaps the reason behind the demand for a deep understand of shale gas plays worldwide.

Shale has already been characterised as a seal or overpressure formation (e.g. Dewhurst and Hennig, 2003; Katsube et al. 1991; Yang and Aplin, 2007) or a problematic formation causing wellbore instability (e.g. Detournay et al. 2006; Sarout and Detournay, 2011; Stjern et al., 2003). There are, however, remarkable differences between shale and conventional reservoirs in terms 
of their geology, mechanical and petrophysical properties (Dewhurst et al. 2015). For instance, deep understanding of shale rocks is demanded for the seismic and passive (microseismic) data analysis, avoiding faults and fractures, and estimation of brittleness parameters used to plan hydraulic fracture treatments (e.g. Aplin et al. 1999). Shale anisotropic characteristics are, on the other hand, needed to have an accurate mechanical earth model for the wellbore stability analysis (Gholami et al. 2015) and to correct electrical logs for estimation of water saturation (Bang et al. 2000; Wei, 2003). Geomechanical parameters of shale reservoirs should also be estimated for the caprock stability analysis, determination of drilling directions and hydraulic fracture initiations (Nygard et al. 2004; Dewhurst et al. 2008; Delle Piane et al. 2011).

Brittleness is one of the most important mechanical properties of unconventional gas shale reservoirs when it comes to hydraulic fracturing (Handin and Hager, 1958; Davis and Reynolds, 1996; Yang et al. 2015). Characterization of brittleness has, therefore, been the focus of many research works in recent years due to successful applications of horizontal wells and hydraulic fracturing in extracting gas from tight shale formations. In fact, there have been more than twenty approaches developed to measure or quantify brittleness using different mechanical and mineralogical parameters (Altindag, 2010; Meng et al. 2014). In mineralogy related discussions, brittle rocks are often considered as those having a high amount of quartz and carbonates but a low clay content, although things may not always be that much simple (Wang et al. 2015). On the other hand, when it comes to rock mechanical parameters based estimation, a low Poisson's ratio and a high Young's modulus corresponds to a brittle rock (Bishop, 1967; Hucka and Das, 1974; Wang et al. 2015). However, the state of stress and confining pressure are crucial parameters required to be well understood during a geomechanical related analysis (Holt et al. 2015).

There have only been few studies so far attempting to characterize shale gas reservoirs for having a successful hydraulic fracturing job. The aim of this study is, therefore, to estimate the brittle index of a gas shale formation located in the north Perth basin of Australia using a log and core sample data analysis. There was also an effort to determine dominant minerals which can be used to predict the ductility/brittleness of shale gas formations. The effect of stress anisotropy was also studied through mechanical tests carried out using a True Triaxial Stress Cell (TTSC) system.

\section{North Perth Basin}

\subsection{Geological Settings}

Perth Basin consists of a series of north to north-northwest trending uplifts, sub-basins and troughs. The basin encompasses about $55000 \mathrm{~km}^{2}$ offshore and $45000 \mathrm{~km}^{2}$ onshore (Song and Cawood, 2000). It is separated from the Yilgarn Craton to the east by the famous Darling fault extending west to the continental edge of the Indian Ocean crust. The stratigraphy of the basin ranges from Permian to Cretaceous ages with a thickness of $15 \mathrm{~km}$ at the Dandaragan Trough.

The basement consists of the Archean and Proterozoic blocks, while some places are overlain by the early Paleozoic sequence-like the Tumblagooda sandstone which is identified in the northern 
part of the basin and coincided with the local block faulting (Playford et al. 1976). Figure 1 shows the structural stetting of the north Perth basin together with its faults and seismic surveys.

The Perth basin is a resultant of a series of extensions causing a complex fault block movement (Song and Cawood, 2000). Its structure was created because of the product of tilted rifting during the Permian, Late Triassic to Early Cretaceous ages. The younger events are related to the last rifting of the Gondwana lithosphere between Australia and the Greater India. It involves dextral strike-slip deformations and basin inversions together with margin orthogonal extensions. Extensions during the Permian produced a series of deep, north-south trending rift basins along the western margin of the Yilgarn Craton. Main hydrocarbon accumulations are within the strikeslip faulted structures, although anticlines have also been successful exploration sites (Song and Cawood, 2000).

\subsubsection{Carynginia formation}

Shale is the main gas source of the Carynginia formation (AWE, 2011), while the overlying unit is mainly sandstone with very little mudstone. The Carynginia shale maintains $300 \mathrm{~m}$ depositional thicknesses across the basin with the localised erosion in the Mid-Permian. An approximate SWNE thick trend is documented and coincided with the isopach map of the Irwin coal measures. This sequence is dominated by more than $90 \%$ mudstone and few lenses of siltstone, sandstone, and limestone. The gas net source thickness ranges from $50 \mathrm{~m}$ to more than $300 \mathrm{~m}$. It is clear that the sequence is mature for gas on the southern part of the Beagle Ridge and the Dandaragan Trough, where the most mature sections are located on the Cadda Shelf of an elevated geothermal gradient. Presently, the unit is mature for oil and immature in the sections toward the north and west as it approaches the surface.

According to Young et al. (2006), the timing of the gas generation from the Carynginia formation is mostly similar to that of the underlying Irwin River coal measures. The peak of gas generations in the Dandaragan Trough section took place in mid to late Jurassic. On the Cadda shelf, the generation began in late Permian and continued to Early Cretaceous. The maturity and kerogen type shows that gas is the most probable hydrocarbon type generated from the Carynginia shale. The earlier phase of oil generation appears to have ceased giving the distribution of hydrocarbons in the basin today. An upward migration from the sequence into the Carynginia limestone, the Wagina sandstone and Basal Triassic sandstone leads to where these reservoir conduits are developed (AWE, 2011). The Carynginia shale is directly beneath the Woodada and Beharra Springs fields which are not fully mature for gas generations. Figure 2 shows the geological stratigraphy of a well, referred to as Well A, drilled in this field and its data was used for the purpose of this study. The Carynginia shale is one of the formations crossed by this well, shown by an upper and lower parts. Table 1 summarises the physical properties of the Carynginia shale obtained from the petrophysical tests on the core samples. 


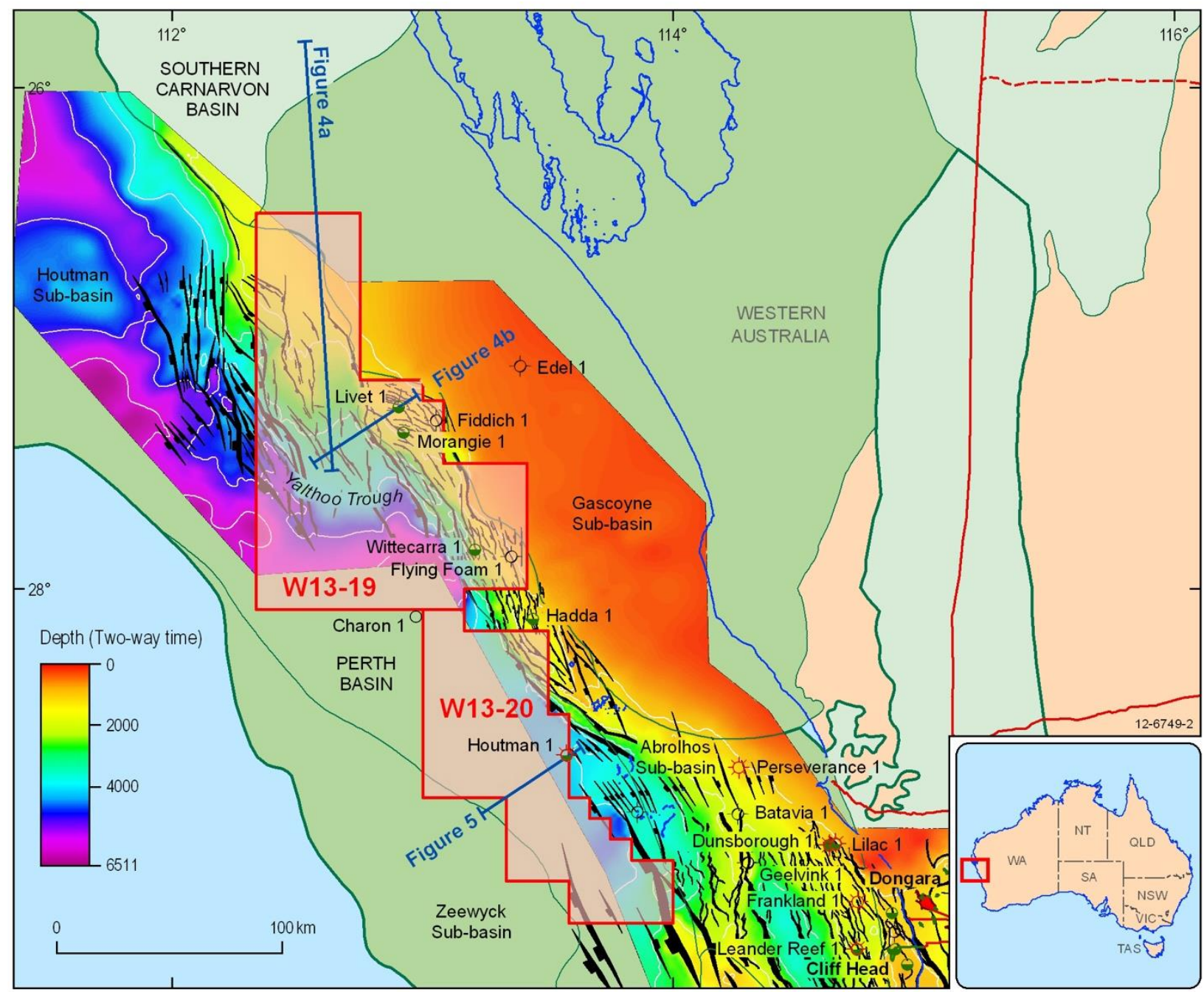

Well symbol information is sourced either from "open file" data from titleholders where this is publicly available as at 1 December 2012 or from other public sources. Field outlines are provided by Encom (the accuracy or completeness of the information, and th is the responsilty of the Customer to ensure by independent means, that those parts of the information used by it are correct before any reliance is phaced on them.
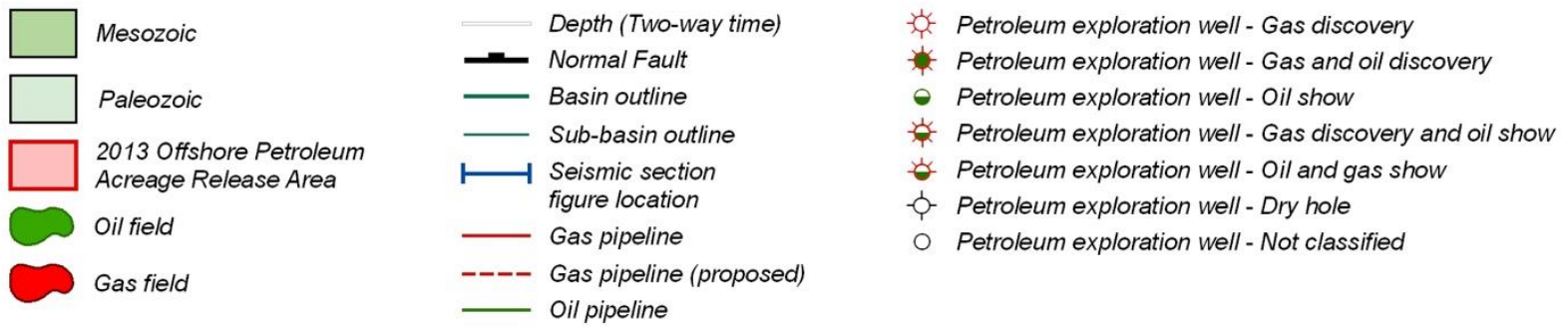

Figure 1: Structural setting of the north Perth Basin, showing petroleum fields, late Permian faults and locations of seismic surveys (Gorter et al., 2004)

\section{Brittleness}

A brittle behaviour in rock mechanics is described as the absence of a permanent (plastic) deformation before ultimate failure (Jaeger et al. 2007). There are, however, some earlier definitions. For instance, Morley (1944) and Hetenyi (1966) defined brittleness as the lack of ductility. Ramsey (1967) indicated that when the internal cohesion of rocks is exceeded, rocks reveal brittle behaviours. Obert and Duvall (1967) expressed brittleness as a property of materials 
which fracture with a little or no plastic flow. From the mechanics of materials point of view, brittleness can be defined using stress-strain data obtained from a uniaxial or triaxial compressive tests as the ratio of the elastic strain to the total strain at failure (Kias et al. 2015). A general definition of brittleness, perhaps, is the one presented by Hucka and Das (1974) stating that fractures are initiated at or only slightly beyond the yield stress of rocks. Having said that, brittleness seems to be a relative measurement depending on the field of study or the purpose of investigations (Altindag, 2010). According to Hucka and Das (1974), as brittleness increases, the following observation might be made:

- low values of elongation of grains;

- fracture failure;

- higher ratio of compressive to tensile strength;

- higher toughness;

- higher angle of internal friction;

- formation of cracks in indentation.

Brittleness is usually expressed by an index indicating how much brittle a rock is (Goktan and Yilmaz, 2005; Rickman et al. 2008; Sondergeld et al. 2010). This index can be estimated using the XRD analysis or mechanical parameters (Sondergeld et al. 2010; Wang et al. 2015). Rickman et al. (2008) were the first ones who proposed the use of Young's modulus and Poisson's ratio to estimate the Brittleness Index (BI). According to them, a brittle rock has a low Poisson's ratio and high Young's modulus. This idea was later confirmed by Sone and Zoback (2013) and Yang et al. (2013) when they have developed their own approaches relating the BI to dynamic elastic parameters. Sondergeld et al. (2010), on the other hand, established a methodology based on the mineralogical analysis to estimate the BI. This kind of approach is very useful for the shale reservoir characterization where brittle minerals are playing key roles to initiate a fracture network (Jarvie et al. 2007). The quartz, feldspar and carbonate are the minerals in this category recognized as brittle components of tight shaly rocks (Chen and Xiao, 2013; Yuan et al. 2015). Generally, brittle rocks comprise a high quantity of quartz and carbonates but the least clay content (Wang et al., 2015). Table 2 summarises some of the approaches developed to estimate the brittleness index using mechanical and mineralogical parameters. 
Table 1: Physical properties of the Carynginia shale (Norwest-Energy, 2011)

\begin{tabular}{|c|c|c|}
\hline Property & \multicolumn{2}{|c|}{ Value } \\
\hline Bulk density ( $\rho b)$ & $2.618-2.619$ & $\mathrm{~g} / \mathrm{cc}$ \\
\hline Total dry grain density (pgrt) & $2.727-2.748$ & $\mathrm{~g} / \mathrm{cc}$ \\
\hline Total porosity $(\varphi \mathrm{t})$ & $5.98-6.75$ & $\%$ \\
\hline Effective porosity $(\varphi \mathrm{e})$ & $2.67-3.80$ & $\%$ \\
\hline Total Organic Content (TOC) & $2.69-3.03$ & wt \% \\
\hline
\end{tabular}

Table 2: Some of approaches developed to estimate the Brittleness Index (after Jin et al. 2015)

\begin{tabular}{|c|c|c|}
\hline Formula & Variable Definition & References \\
\hline$B I_{1}=\varepsilon_{u x} \times 100$ & $\varepsilon_{u x}$ is the unrecoverable axial strain & Andreev (1995) \\
\hline$B I_{2}=\left(H_{m}-H\right) / K$ & $\begin{array}{l}H \text { and } H_{m} \text { are macro- and micro hardness, } K \text { is the } \\
\text { bulk modulus }\end{array}$ & Honda and Sanada (1956) \\
\hline$B I_{3}=q \sigma_{c}$ & $\begin{array}{l}q \text { is the percent of debris smaller than } 0.6 \mathrm{~mm}, \sigma_{c} \text { is } \\
\text { the compressive strength. }\end{array}$ & Protodyakonov (1962) \\
\hline$B I_{4}=\tau_{\max }-\tau_{r} / \tau_{\max }$ & $\begin{array}{c}\tau_{\max } \text { and } \tau_{r} \text { are peak and residual of shear } \\
\text { strengths }\end{array}$ & Bishop (1967) \\
\hline$B l_{5}=\varepsilon_{e} / \varepsilon_{t}$ & $\varepsilon_{e}$ and $\varepsilon_{t}$ are recoverable and total strains & Hucka and Das (1974) \\
\hline$B I_{6}=45^{\circ}+\varphi / 2$ & $\varphi$ is the internal-friction angle. & Hucka and Das (1974) \\
\hline$B I_{7}=H / K_{I C}$ & $H$ is hardness; $K_{I C}$ is fracture toughness & Lawn and Marshall (1979) \\
\hline$B I_{8}=c / d$ & $\begin{array}{l}c \text { is the crack length; } d \text { is the indent size for Vickers } \\
\text { indents at a specified load }\end{array}$ & Sehgal et al. (1995) \\
\hline$B l_{9}=\left(\sigma_{c}-\sigma_{t}\right) /\left(\sigma_{t}+\sigma_{c}\right)$ & $\sigma_{c}$ and $\sigma_{t}$ are compressive and tensile strength & Altindag (2003) \\
\hline$B I_{10}=\left(\varepsilon_{p}-\varepsilon_{r}\right) / \varepsilon_{p}$ & $\varepsilon_{p}$ is peak of strain; $\varepsilon_{r}$ is residual strain & $\begin{array}{l}\text { Hajiabdolmajid and Kaiser } \\
\text { (2003) }\end{array}$ \\
\hline$B I_{11}=\left(W_{\mathrm{qtz}}\right) / W_{\text {Tot }}$ & $\begin{array}{c}W_{\text {qtz }} \text { is the weight of quartz; } W_{\text {Tot }} \text { is total mineral } \\
\text { weight }\end{array}$ & Jarvie et al. (2007) \\
\hline$B I_{12}=\left(E_{B}+v_{B}\right) / 2$ & $\begin{array}{l}E_{B} \text { and } v_{B} \text { are normalized dynamic Young's } \\
\text { modulus and dynamic Poisson's ratio }\end{array}$ & Rickman et al., (2008) \\
\hline$B I_{13}=\left(W_{\mathrm{qtz}}+W_{\mathrm{dol}}\right) / W_{\text {Tot }}$ & $\begin{array}{c}W_{\text {qtz }} \text { and } W_{\text {dol }} \text { are weights of quartz and dolomite; } \\
W_{\text {Tot }} \text { is total mineral weight }\end{array}$ & Wang and Gale (2009) \\
\hline$B I_{14}=F_{\max } / P$ & $\begin{array}{l}F_{\max } \text { is the maximum applied force on the specimen; } \\
\qquad P \text { is the corresponding penetration }\end{array}$ & Yagiz (2009) \\
\hline $\begin{array}{c}B I_{15}=(Q z+F e l s+\text { Car }) / \\
(Q z+F e l s+\text { Car+Clay })\end{array}$ & $\begin{array}{l}\text { Qz is quartz content, Fels is feldspar content; } \\
\text { Car is the carbonate content, Clay is clay } \\
\text { content }\end{array}$ & Guo et al., (2015) \\
\hline
\end{tabular}

In the following sections, the $\mathrm{BI}$ of the Carynginia shale is estimated to evaluate its potential for a successful hydraulic fracturing job.

\subsection{Well Log based Brittleness}

Three approaches were taken into consideration, in this study, to estimate the $\mathrm{BI}$ of the shale formation, including a log based, mineralogy based and mechanical tests based data analysis. For the log based data analysis, dynamic elastic parameters are often used to predict brittleness. 


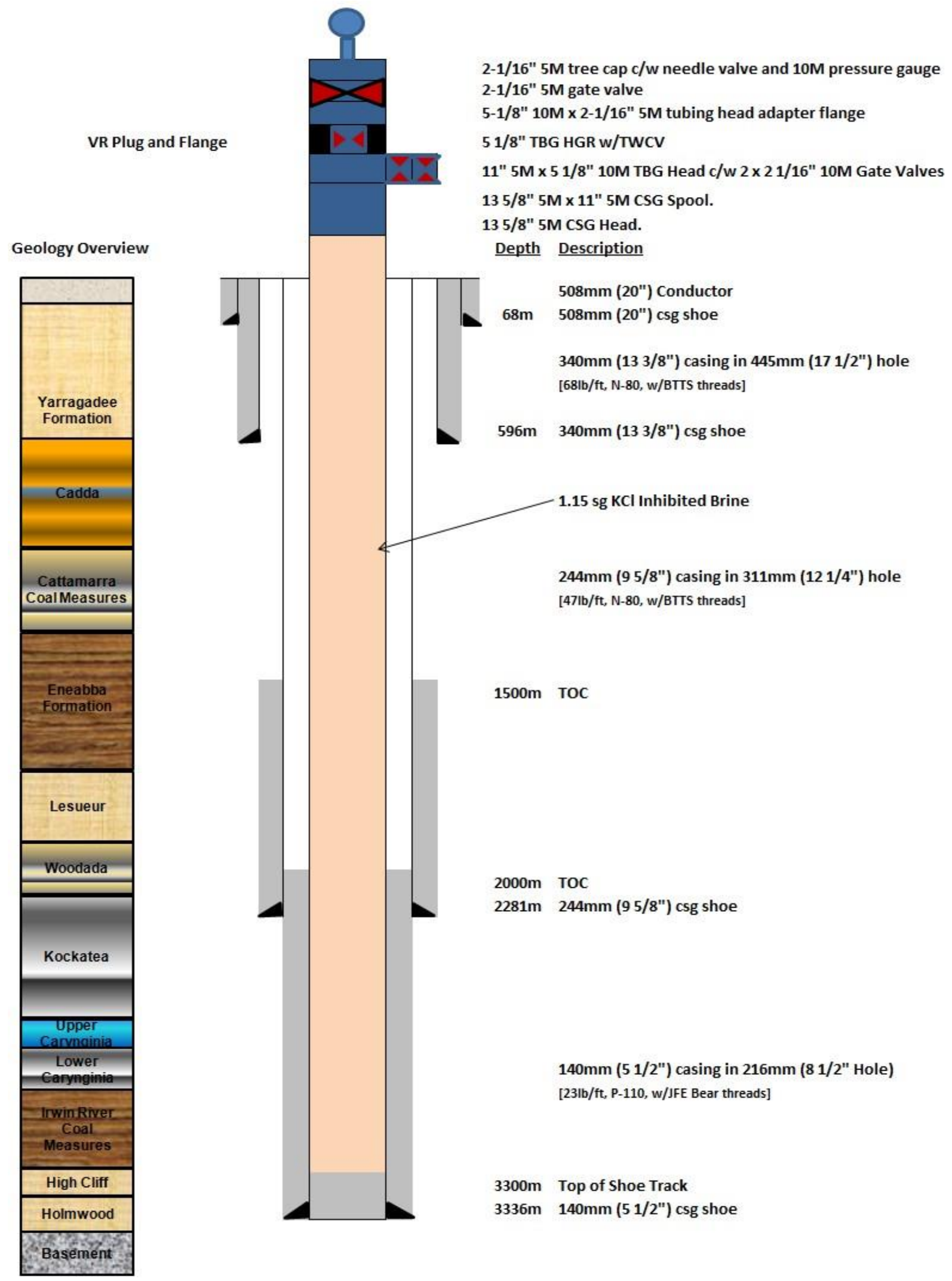

Figure 2: Stratigraphy and completion of Well A (Norwest-Energy, 2011) 
Dynamic elastic parameters can be estimated using the density of rocks together with the velocity of P- and S-waves (Fjaer et al., 2008; Gholami et al. 2015). However, due to the variation of Young's modulus and Poisson's ratio, the results obtained should be normalized by maintaining the trend of the original data. This normalization can be carried out using the following equations (Yuan et al. 2014):

$$
\begin{aligned}
& E_{B}=\frac{E-E_{\text {Min }}}{E_{\text {Max }}-E_{\text {Min }}} \\
& v_{B}=\frac{v-v_{\text {Max }}}{v_{\text {Min }}-v_{\text {Max }}}
\end{aligned}
$$

The $\mathrm{BI}$ can then be estimated using $\mathrm{Bl}_{12}$ which has been brought in Table 2. Having the density (RHOB) and DSI log data (i.e., containing P- and S-wave velocities) of the production interval of Well A, the BI was estimated and shown in the last track of Figure 3.

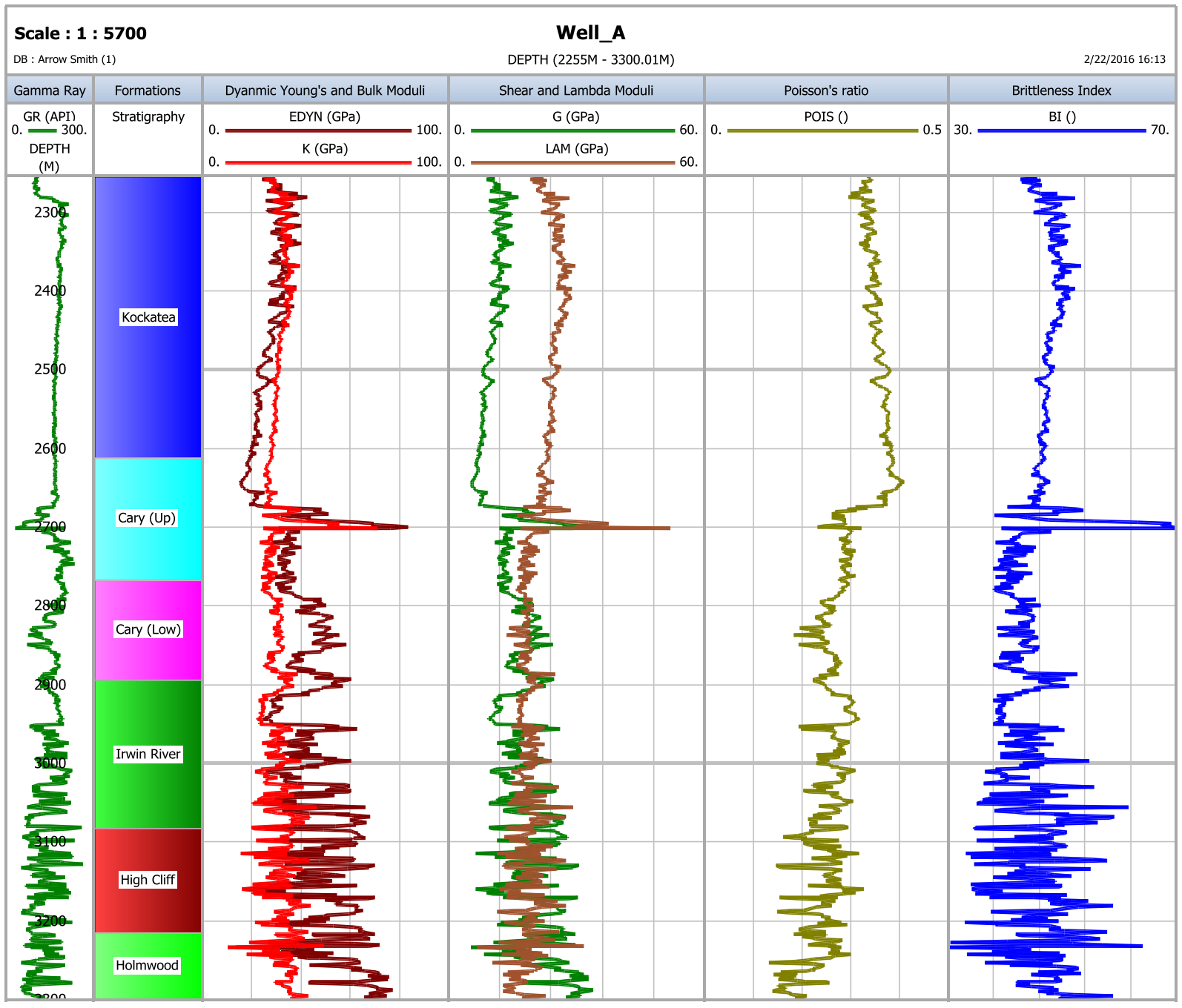

Figure 3: Elastic parameters and brittleness index of the production interval of Well $A$ having the Carynginia shale formation represented by its upper and lower parts 
From Figure 3, it can be concluded that there are differences between brittleness of the upper and the lower parts. The upper part, in fact, displays a relatively high Poisson's ratio and a low Young's modulus which are probably due to high clay contents of the formation. The lower part, on the other hand, indicates a high Young's modulus and low Poisson's ratio which are mainly due to its high non-clay content. Knowing that a high Young's modulus and low Poisson's ratio is the sign of having a brittle rock, it seems that the lower part of the Carynginia shale is more sophisticated than the upper one for having a safe hydraulic fracturing. Figure 4 compares the Young's modulus and Poisson's ratio of the upper and lower parts of the Carynginia shale formation.
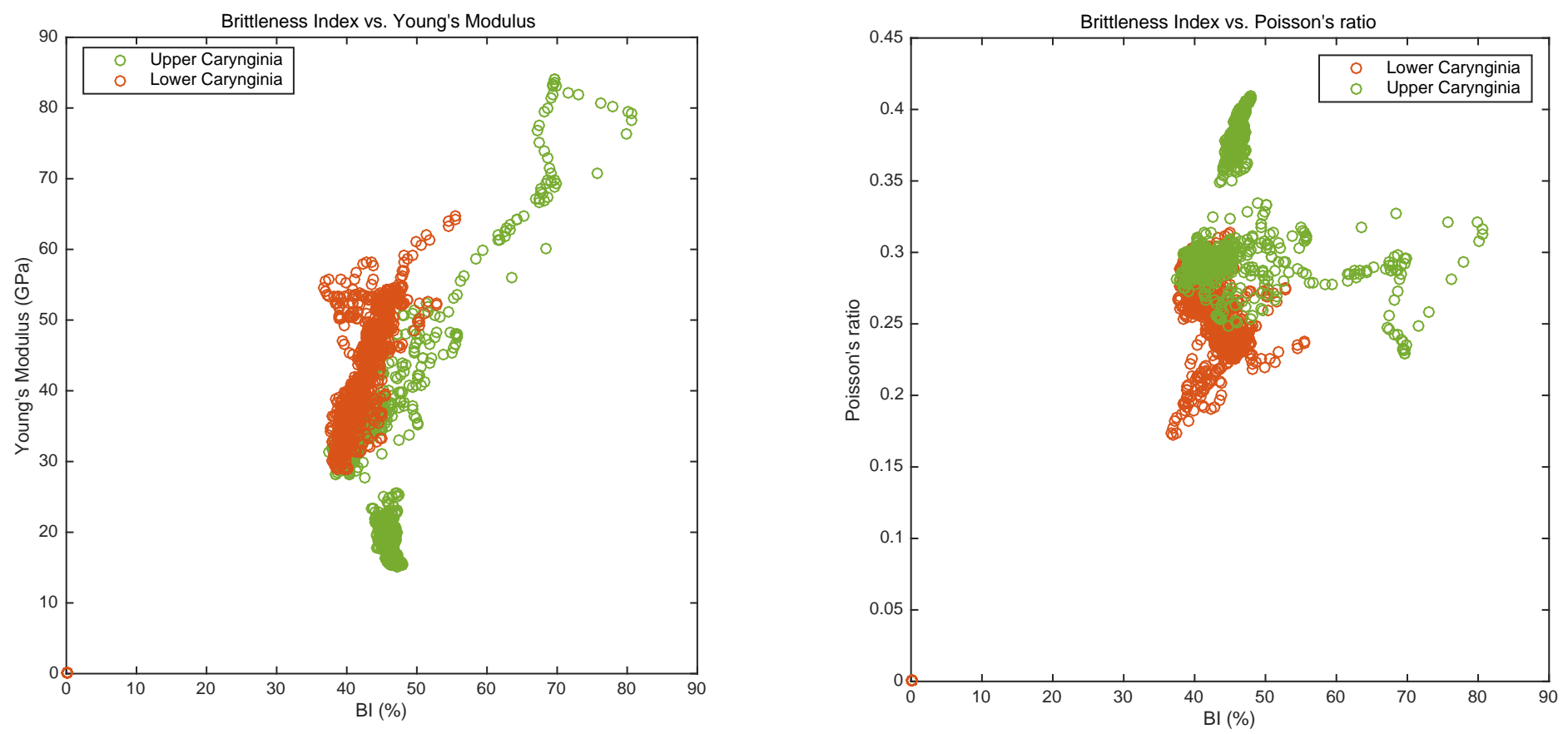

Figure 4: Variation of Young's modulus (left) and Poisson's ratio (right) with the BI in the upper and lower parts of the Carynginia shale

For a further analysis and determination of the parameters linked to brittleness, cross-plots of gamma ray versus brittleness and Young's Modulus were created, as shown in Figure 5 . The results obtained indicated that exceptionally high-GR values (>220 API) correspond to the layers containing highly radioactive minerals with a low Young's modulus. The cross-plot also shows that as the Total Organic Content (TOC) of the shale formation increases with increasing the gamma ray, brittleness (and Young's modulus) decreases. It can be concluded that the lower part of the Carynginia formation would be a good candidate for hydraulic fracturing due to having a relative high brittleness, although caution should be taken to evaluate the TOC as it must be high enough 
for having a good reservoir. Figure 6 shows the cross-plot of Young's modulus versus Poisson's ratio used to discriminate brittle and ductile regions of the shale formation.
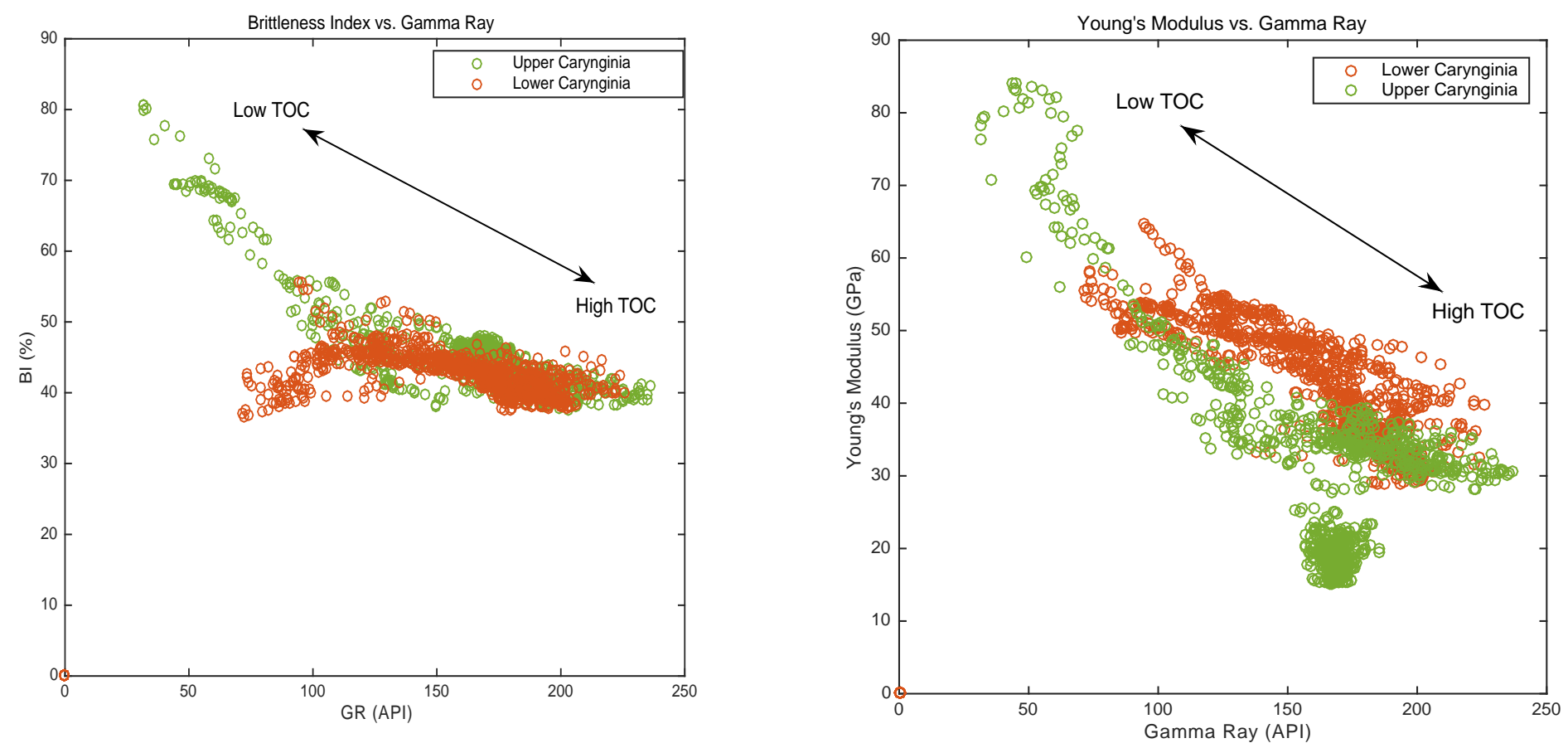

Figure 5: Cross-plots of BI (left) and Young's modulus (right) versus Gamma ray readings

Two regions were highlighted in Figure 6 based on the variation of Young's modulus and Poisson's ratio which represent the ductile and brittle intervals of the shale. The brittle region, which probably corresponds to the lower part of the formation, can be defined by a Poisson's ratio and Young's modulus of 0.17 to 0.27 and 35 to $65 \mathrm{GPa}$, respectively. The ductile region, which represents the upper part of the Carynginia, would be the area with a Poisson's ratio and Young's modulus of 0.3 to 0.4 and 10 to $30 \mathrm{GPa}$, respectively. These properties might be very useful for the reservoir characterization when brittle and ductile intervals cannot be easily discriminated due to limited knowledge and complicated geological settings (Perez and Marfurt, 2014).

The cross-plot of shear modulus $(G)$ versus Lambda modulus (also known as lame's first parameter or $\lambda$ ) is an approach developed for petrophysical characterizations and determination of minerals contributing into brittleness. Goodway et al. (1997) showed that lithology and pore fluid information can be extracted from $\mathrm{G}-\lambda$ cross-plots derived from the surface seismic or well logs data. Berryman et al. $(1999,2002)$ created several $\lambda-G$ cross-plots and successfully discriminated different kinds of shale with various porosity and saturation degrees. This template was later used to compare shale and carbonate lithologies worldwide by providing a grid of mineral references (Simon, 2005). Goodway et al. (2006) highlighted that as porosity, fluid content and crack density of shale increase, a shift can be observed in the G-axes of the cross-plot. This shift is attributed to gas saturation which decreases the values of lambda toward the origin. Goodway et al. (2010) 
used this approach to evaluate the brittleness and minerals of Western Canadian (red and green) and the Barnett (yellow) gas shales. They concluded that both of them are far to be ductile due to their quartz contents and rigidity (shear modulus). Later, Perez (2011) presented a lithology template for $\mathrm{G}-\lambda$, connecting three vertices of quartz, calcite and clay to generate a mineralogy ternary plot which could identify brittleness/ductility of various shales.

To use this template, shear and lambda moduli were estimated from their relationships with Young's modulus and Poison's ratio as presented in the third track of Figure 3. As a result, a crossplot was created showing the variation of these two parameters against each other. Three vertices of quartz, clay and calcite were then connected, generating the mineralogy plot in the G$\lambda$ space. Figure 7 shows the cross-plot created based on the above discussions.

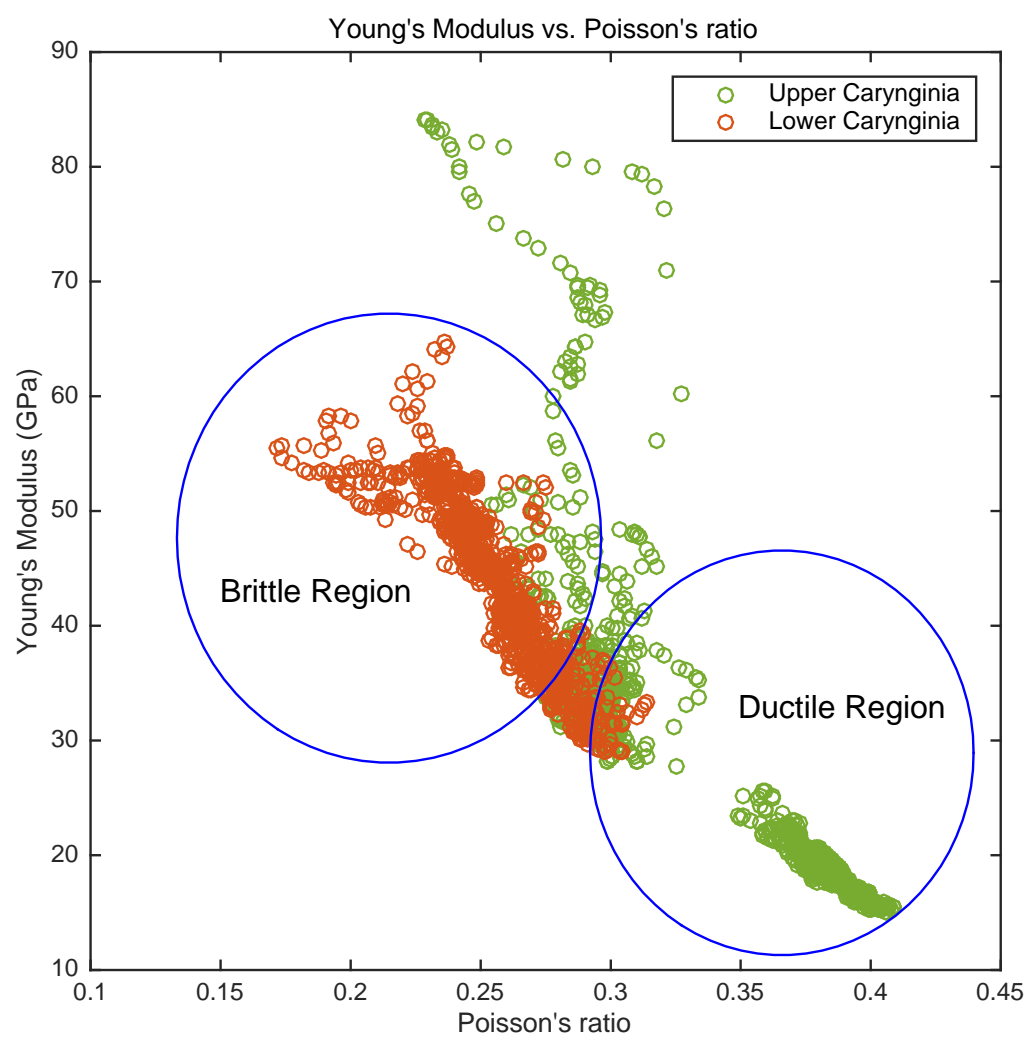

Figure 6: Cross-plot of Young's modulus versus Poisson's ratio for Well A 


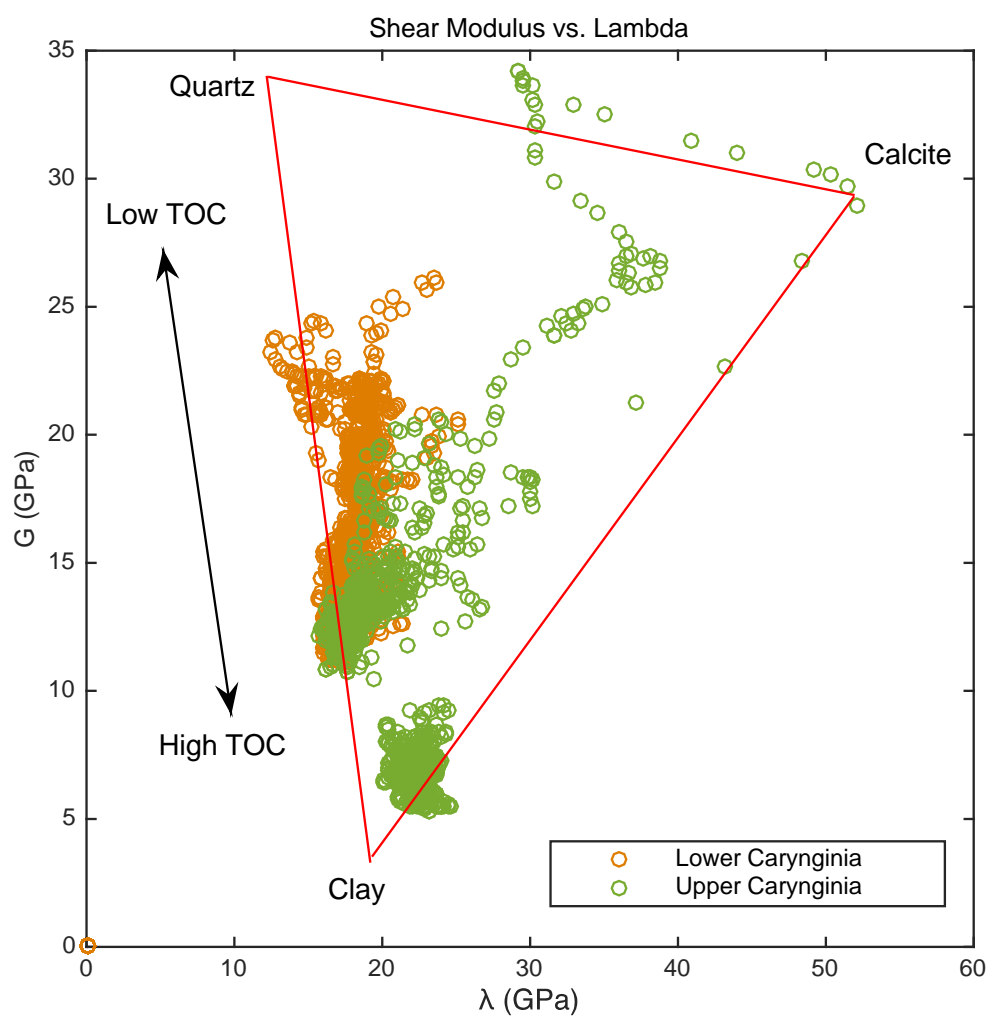

Figure 7: Cross-plot of shear modulus vs. lambda modulus used for the mineralogical analysis

From Figure 7, it can be concluded that dominant minerals of the Carynginia formation are quartz and clay. This means that quartz is the only mineral contributing into brittleness and calcite (or carbonates) cannot be used for estimation of the BI. This conclusion will be further discussed in the next section by bringing mineralogical plots.

\subsection{Brittleness and Mineralogy}

Making the interpretation based on mineralogy is one of the strategies taken to differentiate brittle from ductile rocks. It is known that brittleness is mainly controlled by the quartz content while ductility is measured by clays, calcite, and TOC (Wang and Gale, (2009). In this section, the $\mathrm{BI}$ of the Carynginia shale was estimated based on its mineralogical characteristics and a conclusion was made as to which one of these minerals is the best indicator of brittleness.

Mineralogy data were acquired from the XRD analysis of the core samples taken from different intervals of Well A (See Figure 8). The results obtained were categorised into non-clay and clay classes, in which quartz, feldspar, carbonates, pyrite, barite and magnetite were in the non-clay category, while illite, smectite, mica, kaolinite and chlorite were in the clay category.

This mineralogical report revealed that the upper part of the Carynginia consists mainly of a relatively low quartz (average $24 \%$ ) but a high clay (average 50\%) content. It was also found that the percentage of quartz increases towards the lower part of the formation with an average of 
$50 \%$ while that of the clay is higher in the upper part with an average of $30 \%$. A significant amount of feldspar was also recorded in the formation with a range of $9 \%$ to $20 \%$. The presence of carbonates in the formation, however, was quite low with an average of $6 \%$. TOC of the shale formation follows the trend of clay minerals (Norwest-Energy 2011). It seems that TOC of the upper part is higher with an average of $3 \%$ while the lower part, which was dominated by quartz, was only having a TOC of $1 \%$. These results were aligned with those obtained from the log data analysis indicating that the interpretation made through the cross-plots of elastic parameters has a sufficient degree of accuracy. However, due to the amount of TOC recorded, it would be wise to do more analysis before initiating fractures in the lower part of the formation only based on brittleness.

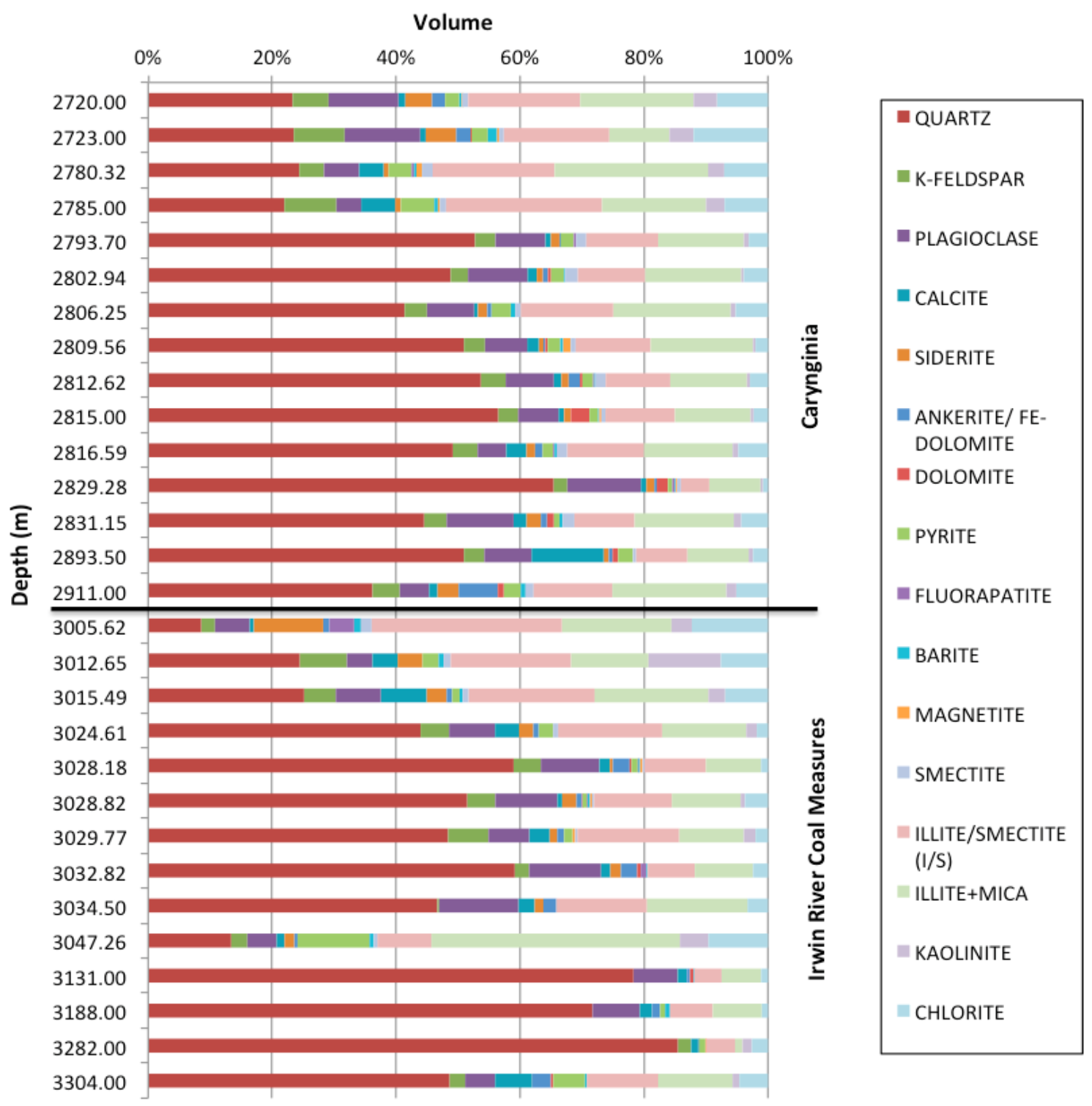

Figure 8: Percentage of minerals obtained from the XRD analysis of the core samples taken from different intervals of Well A (Norwest-Energy 2011) 
Having the report pertaining the details of mineralogy, attempts were made to make cross-plots of different minerals against the dynamic elastic parameters obtained earlier from the log data analysis. These cross-plots may help to identify which one of these minerals is the main indicators of brittleness in the Carynginia formation. Figures 9 to 12 displays the cross-plots of the mechanical parameters versus different minerals.
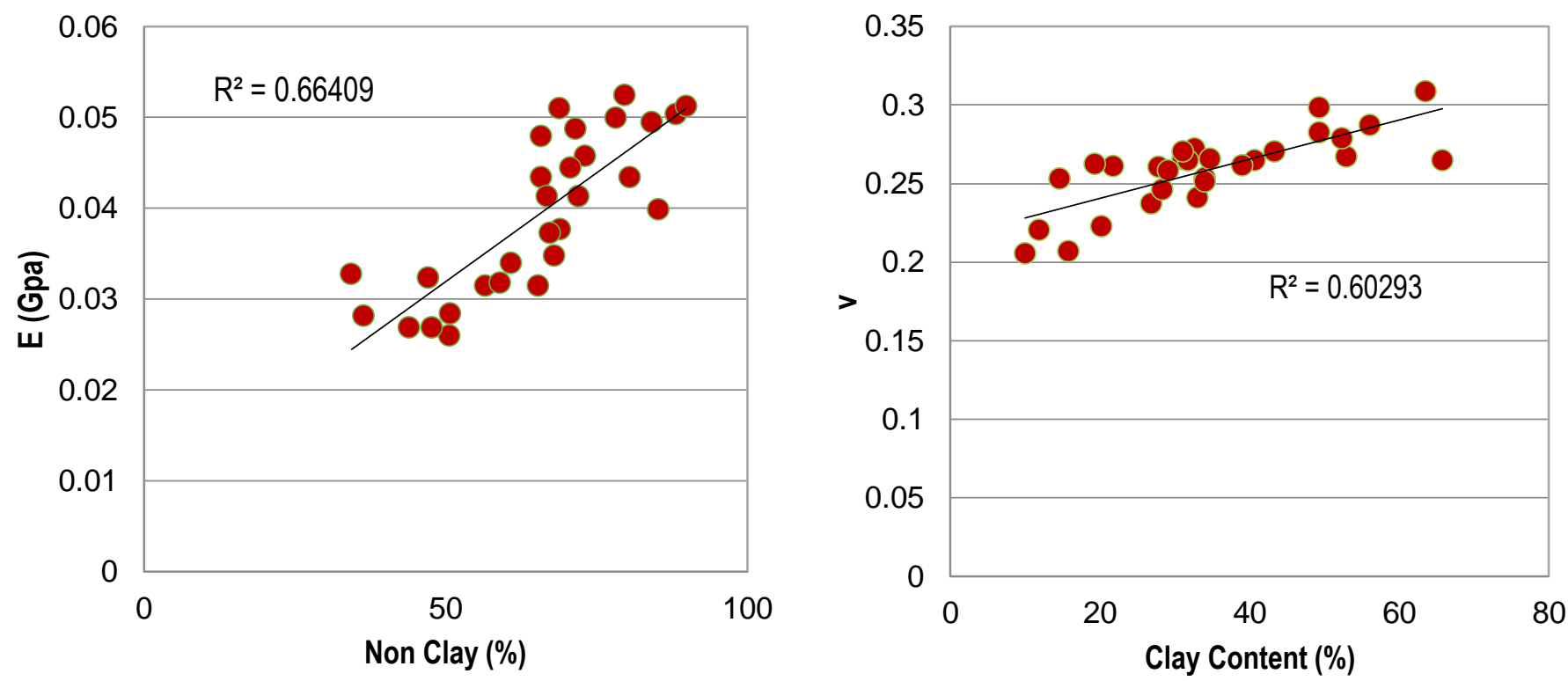

Figure 9: Variations of Young's Modulus (E) versus Non-Clay minerals (left) and changes in the magnitude of Poisson's ratio with respect to the clay content (right)
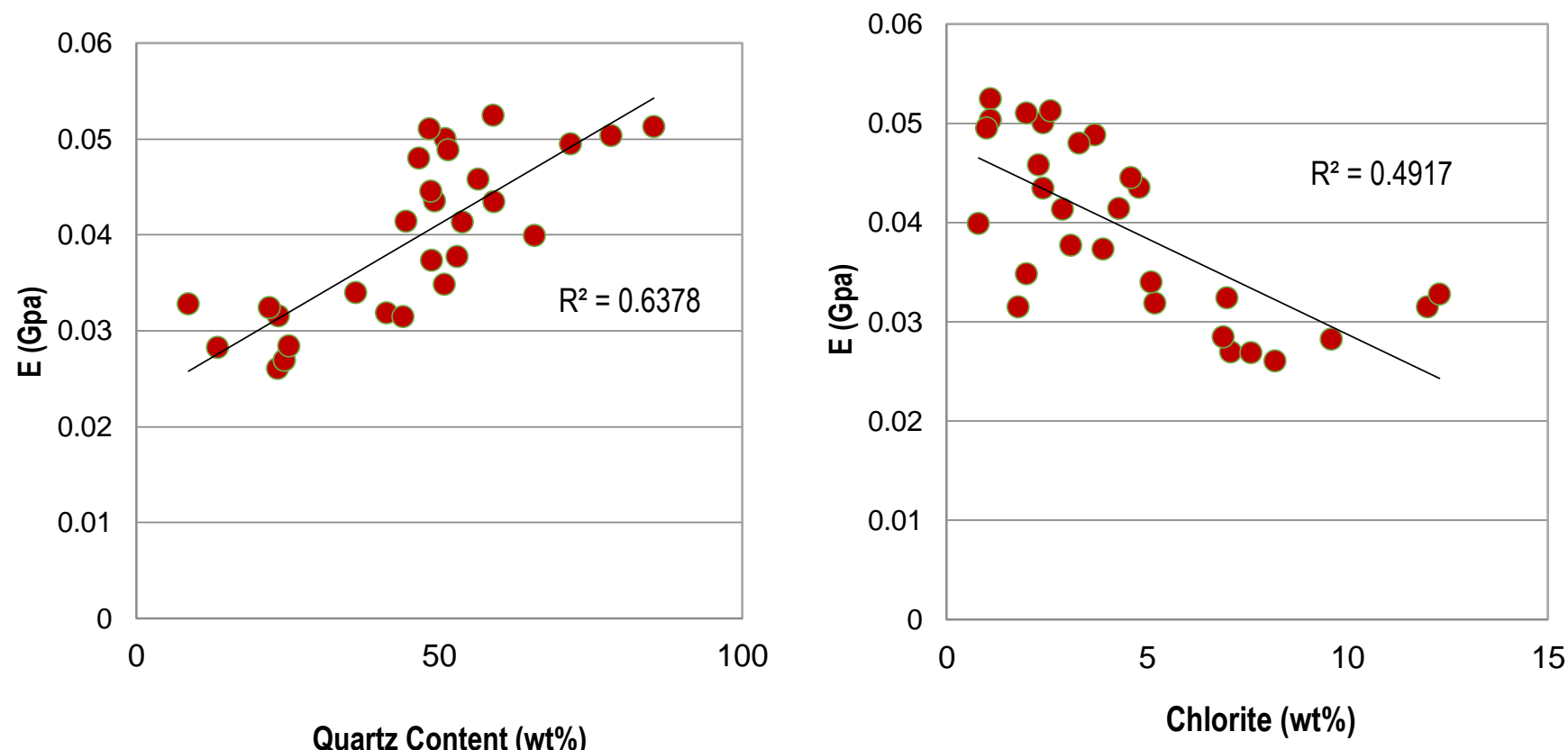

Quartz Content (wt\%)

Figure 10: Variations of Young's Modulus (E) versus quartz (left) and Chlorite (right) 

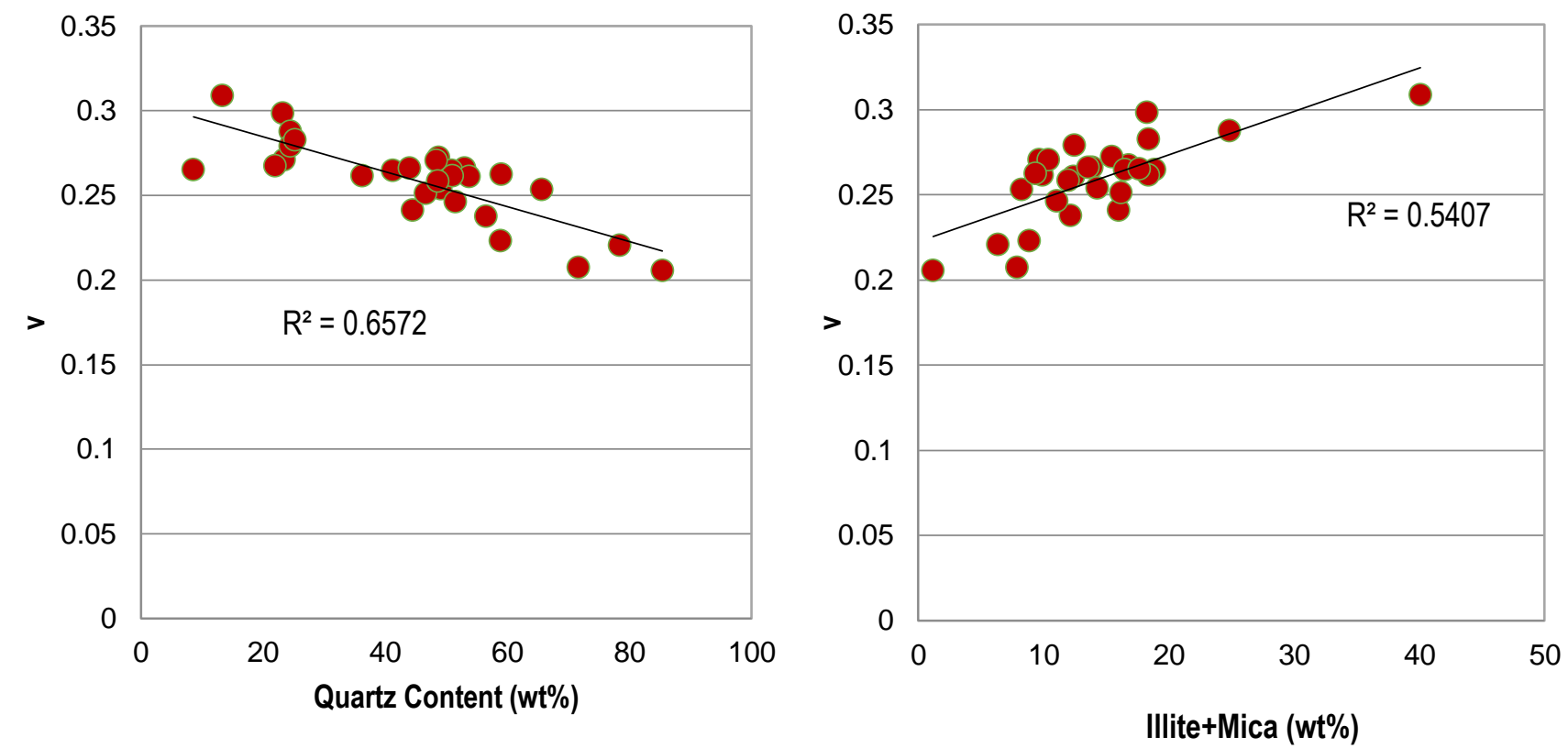

Figure 11: Variations of Poisson's ratio (v) versus quartz (left) and Illite-Mica (right)
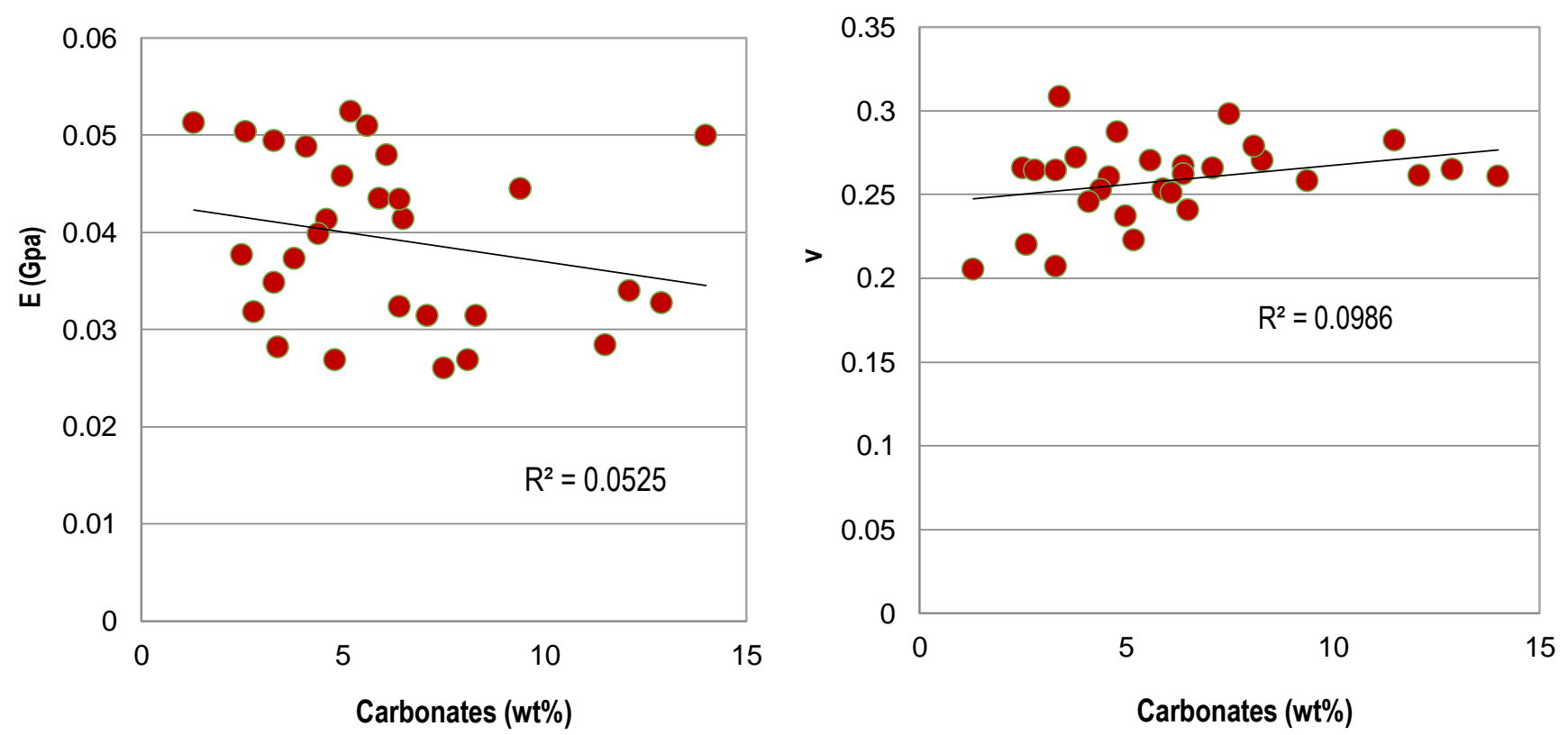

Figure 12: Variations of carbonates versus Young's Modulus (left) and Poisson's ratio (right)

Looking at the figures shown above, it seems that quartz is the only indicator of brittleness in the shale formation. Illite and mica, on the other hand, are representatives of ductile behaviours. The 
variation of mechanical parameters is scattered when it comes to carbonates and, therefore, carbonates cannot be used as a representative of brittleness/ductility in the Carynginia.

To estimate the BI using the dominated minerals, the equation developed by Guo et al., (2015) (i.e., $B_{15}$ in Table 2) was used. According to Guo et al., (2015), when the BI is less than $40 \%$, the rock is brittle and when the $\mathrm{BI}$ is bigger than $60 \%$, the rock is highly brittle.

Estimations made based on the above approach revealed that the $\mathrm{BI}$ for the upper and lower sections of the Carynginia shale is around $39 \%$ and $70 \%$ respectively, suggesting a ductile formation at the top and a brittle one at the bottom.

In the next section, an experimental results based analysis is performed to determine the BI of the shale using the stress-strain plots obtained from a true triaxial stress cell.

\subsection{Mechanical tests based Brittleness}

Triaxial compressive tests have been used to evaluate the effect of the confining pressure on the brittleness index of rocks including shale (Holt et al., 2011; Yi et al., 2013; Geng et al., 2015; Holt et al., 2015). However, in many occasions, particularly in tectonically active regions, horizontal stresses are not the same and stress anisotropy should be taken into consideration to achieve a reliable result (Zoback, 2007). In this section, a true triaxial stress cell system in which three independent stresses can be applied on a cubic sample, is used to evaluate the Carynginia shale brittleness under different states of stress.

\subsubsection{Core Samples}

The Carynginia shale core samples used for the purpose of geomechanical analysis were carefully cut and machined into cubes of $5 \mathrm{~cm}$ edges $\left(125 \mathrm{~cm}^{3}\right)$. All cubes were dry-cut with a normal saw to reduce the risk of opening cracks along the bedding planes due to oil intrusion. Oil was used, as a flushing and cooling fluid, to remove the cuttings and prevent the desiccation of the samples during the cutting. Samples were then wrapped in a plastic film to prevent changes in their water content which may alter the elastic, strength and deformation properties of rocks when it comes to true triaxial tests (Dewhurst and Hennig., 2003). According to Ghorbani et al., (2009), loss of pore water in tight shales increases the strength and stiffness of samples. Figure 13 shows a cubic core sample of the Carynginia shale together with glass desiccators used to saturate the samples. It should be noticed that the direction of three principal stresses applied is also written on the core sample. 

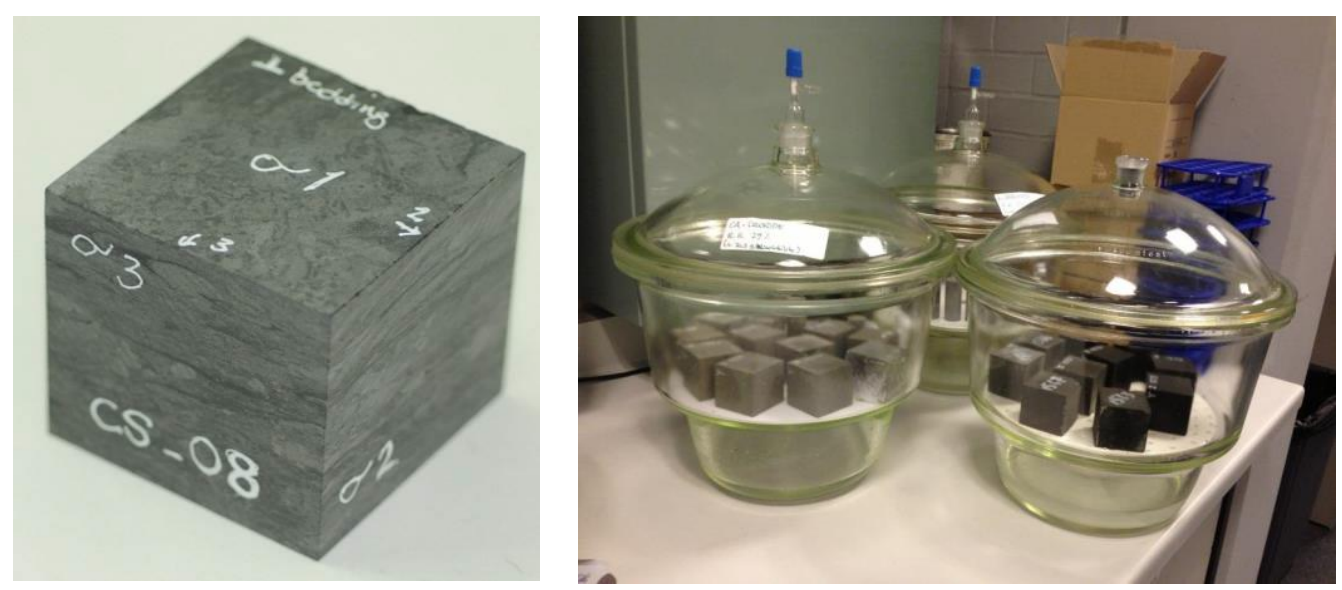

Figure 13: Carynginia cubic sample (left) and relative humidity environments established in glass desiccators for saturation of samples

\subsubsection{Saturation Control}

The underlying principles of the saturation control used in this study are similar to the sorption bench technique used for clay based materials. The Relative Humidity $(\mathrm{RH})$ environment was created inside a closed desiccator and controlled by a saturated saline solution. Different RH levels were then obtained by selecting the salt type. The rock samples can then be periodically weighed until the weight stabilizes and an equilibrium is reached. Figure 14 shows the time it takes under two different RH environments for the cube samples to get fully saturated.

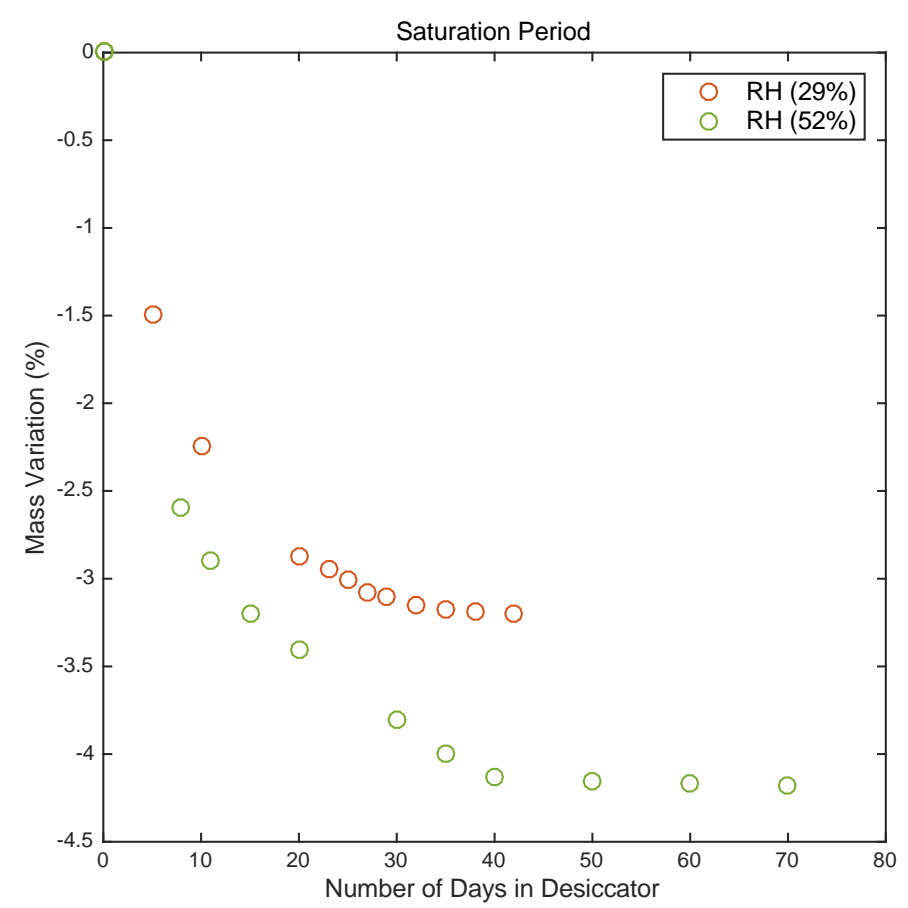

Figure 14: Mass variations of the samples as a function of number of days in desiccators with different relative humidity 


\subsubsection{True Triaxial Stress Cell}

Mechanical tests were conducted using a true triaxial stress cell (TTSC) in which three independent stresses could be applied on cubic rock samples by three pairs of hydraulic rams (Rasouli and Evans, 2010). Generally, the equipment comprises a high stiffness load frame, a pressure vessel and independent pumps. The operational limits of the apparatus are $70 \mathrm{MPa}$ confining pressure, $70 \mathrm{MPa}$ pore pressure and $400 \mathrm{MPa}$ axial stress. The sample assembly includes: 1) a cubic sample mounted between top and base platens, 2) an impermeable Viton membrane isolating the specimen from the confining fluid, 3) two steel platens housing ultrasonic $\mathrm{P}$ - and S- transducers, and 4) two linear variable differential transformers (LVDT) placed on the platens to measure the axial displacement. Figure 15 shows a schematic view of the TTSC system. In the tests, two horizontal stresses are kept constant while the vertical stress is increased until the sample undergoes failure. The applied stresses are then changed in a series of tests to investigate the dependency of mechanical parameters to stress conditions, say stress magnitude and anisotropy. In this study, however, the minimum and intermediate principal stresses were applied in lateral directions, and the maximum principal stress was in the vertical direction. This applies the maximum stress perpendicular to the bedding planes, although this may give the maximum strength of the sample (Gholami and Rasouli, 2014). The TTSC is not a servo-control apparatus in its current set-up and only works under stress-controlled mode. Therefore, the loading rate was chosen according to similar experiments reported in the literature (Naumann et al., 2007; Popp and Salzer, 2007; Ma and Haimson, 2013).

This cell has been designed to accommodate different cubic sample dimensions of up to $300 \mathrm{~mm}$ edge length. The samples used for the purpose of this study were cubes samples with the length of $50 \mathrm{~mm}\left(125,000 \mathrm{~mm}^{3}\right)$ and, therefore, a plastic block was used to position the specimen at the centre of the cell to have an accurate measurement. Three pairs of metal shims were then placed inside the holes of the plastic block around the sample to fill the existing gaps and transfer the load from the machine to the specimen faces. Graphite powder was used to reduce the friction between the rock faces and the metal shims. It should be noticed that the cell does not allow to observe the samples during the tests and evaluations should be made after accomplishing the tests.

\subsubsection{Measurements}

Stress and strains measurements were done in three normal directions during the tests and pressure readings were carried out using sensors with a resolution of $0.002 \%$ and an accuracy of $0.1 \%$ at 10 to $40^{\circ} \mathrm{C}$. Measuring and recording the rock displacement during the tests was crucial to evaluate the rock strength and elastic properties. Deformation (strain) measurements were done using the LVDT with a maximum mechanical travel of $7.87 \mathrm{~mm}$, sensitivity of $165.7 \mathrm{mV} / \mathrm{mm}$

and resolution of $6 \mu \mathrm{m}$. The LVDT was calibrated prior to the tests and the non-linearity of the device could not have any impacts on the measurements. 
The loading path is perhaps the most significant parameters of the test. Many studies have been done so far proposing a stress path for a true triaxial test (e.g., Mogi 1971, Wawersik et al. 1997, Naumann et al. 2007, Ma and Haimson 2013). For the purpose of this study, however, the approach presented by Ma and Haimson (2013) was applied due to the capacity of the cell. Therefore, in each test, all three stresses were initially increased quasi-isotropically but the stress in the maximum $\left(\sigma_{1}\right)$ direction was slightly larger than the intermediate $\left(\sigma_{2}\right)$ direction and that was slightly larger than the least $\left(\sigma_{3}\right)$ direction. When the stresses reached the minimum magnitude (i.e., 2MPa), $\sigma_{3}$ was maintained and two other stresses were increased simultaneously to reach the planned intermediate stress at which $\sigma_{2}$ was kept constant and the maximum stress was increased until failure took place. Table 3 gives the stress conditions used during the test together with strength and elastic parameters obtained.

Table 3: Stress conditions during true triaxial testing of the Carynginia shale samples

\begin{tabular}{|c|c|c|c|c|c|c|}
\hline Sample ID & $\sigma_{2} / \sigma_{3}$ & $\sigma_{3}(\mathrm{MPa})$ & $\sigma_{2}(\mathrm{MPa})$ & $\sigma_{1}(\mathrm{MPa})$ & $\mathrm{E}(\mathrm{GPa})$ & $\mathbf{v}$ \\
\hline CS-01 & 1 & \multirow{5}{*}{3.4} & 3.4 & 72 & 7.6 & 0.25 \\
\hline CS-02 & 3 & & 10.3 & 78 & 7.8 & 0.25 \\
\hline CS-03 & 5 & & 17.2 & 76 & 7.7 & 0.25 \\
\hline CS-04 & 6 & & 20.7 & 58 & 6.5 & 0.26 \\
\hline CS-05 & 7 & & 24.1 & 71 & 7.4 & 0.18 \\
\hline CS-06 & 1 & \multirow{5}{*}{6.2} & 6.2 & 80 & 9.1 & 0.19 \\
\hline CS-07 & 3 & & 18.6 & 88 & 9.6 & 0.17 \\
\hline CS-08 & 5 & & 31 & 86 & 9.4 & 0.20 \\
\hline CS-09 & 6 & & 37.2 & 76 & 7.2 & 0.24 \\
\hline CS-10 & 7 & & 43.4 & 84 & 9.1 & 0.21 \\
\hline
\end{tabular}

Given in Table 3, as the stress anisotropy in horizontal directions increases, significant changes are observed in the magnitude of strength and elastic parameters. In fact, strength and Young's modulus seem to be a function of stress anisotropy but their trends are quite complicated. Looking at the results, one can conclude that the maximum strength and Young's modulus decreases with increasing the differential stresses, but suddenly increases when the ratio of horizontal stresses becomes very high (close to 7). The variation of Poisson' ratio ( $v$ ), on the other hand, is apparently following an opposite trend, although it is not that much simple to be detected. 


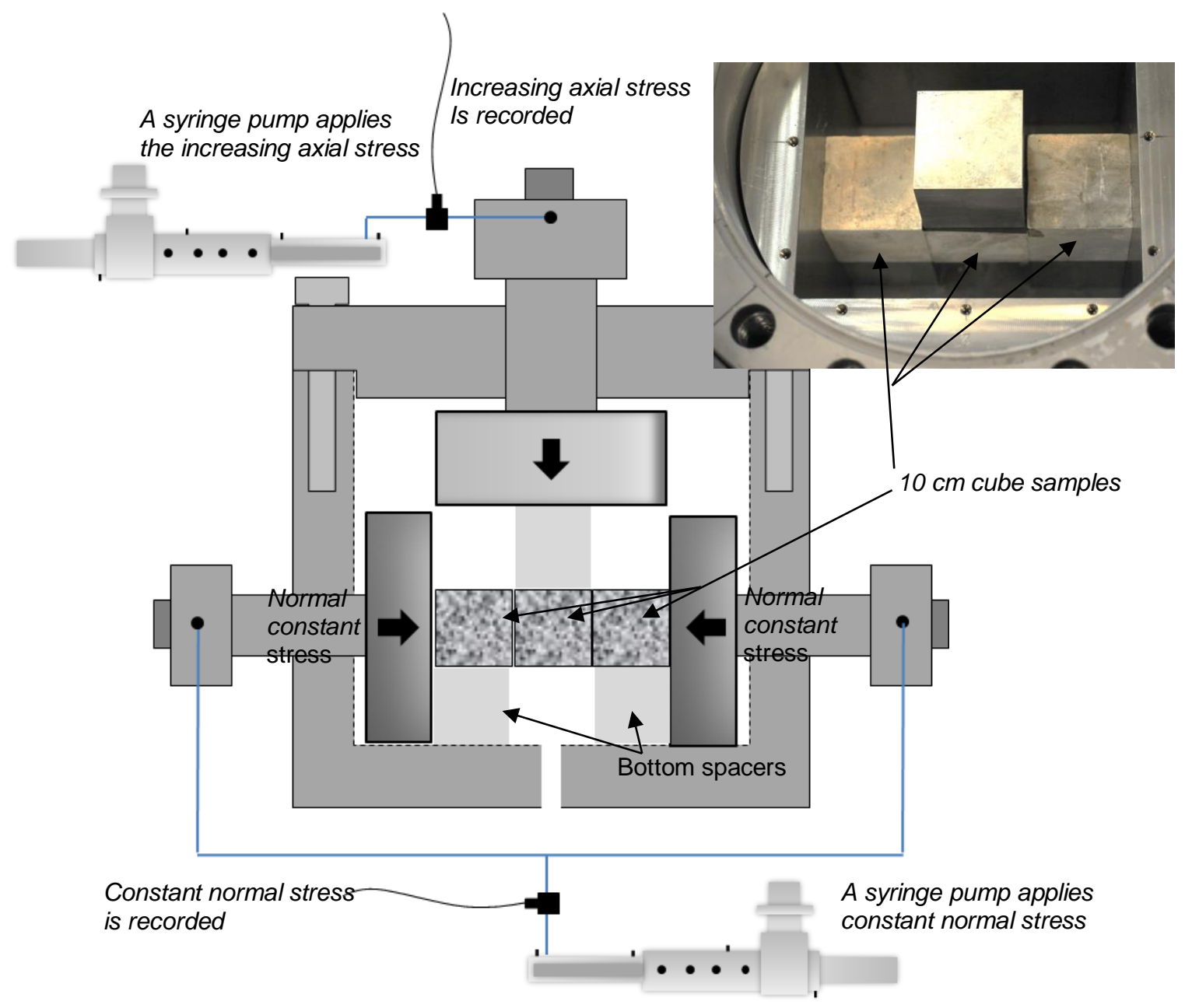

Figure 15: Schematic view of the True Triaxial Stress Cell (TTSC) (Sarmadivalleh, 2012)

There are several approaches developed to estimate brittleness of rocks including those brought in Table 2. However, two of them are often employed to evaluate the possibility of having a network of fractures in gas shales, including $\mathrm{Bl}_{4}$ and $\mathrm{Bl}_{5}$. A schematic representation of the stressstrain graph from which parameters introduced in these two approaches can be determined is shown in Figure 16.

Figure 16 suggests that there is a transition from elasticity to plasticity with a deviation from linearity which can be used for the estimation of brittleness, but it is not always easy to identify this trend due to the complexity of the curve shape. One can use unload-reload cycles to find the elastic strain in these cases, but such studies are rarely carried out on gas shale samples through rock mechanical tests (Holt et al., 2015). 
Many of the approaches developed to estimate the BI require experimental (mechanical) tests on core samples. It should be noticed that brittleness depends mainly on the confining pressure applied to reach failure. Therefore, when servo-controlled machines are used and confining pressures are similar, data may have sufficient accuracy, but cannot be compared to a same set of data obtained from any other experimental tests.

\subsubsection{Experimental tests results}

Core samples used for the geomechanical tests were partially to fully saturated and were visually seen to be anisotropic, indicating the fact that mechanical parameters may not be the same in different directions. Due to having a limited number of samples and difficulties of interpretations, all of the measurements made through the TTSC were normal to the bedding plane (i.e., the angle between maximum applied stress and bedding planes was 90 degree) and this may give the maximum strength of the samples (Gholami and Rasouli, 2014). Two values of 3.4 and 6.2 MPa were considered for the least principle stress while the intermediate stress was changing from 3.4 to 24.1 MPa during the tests as mentioned earlier and brought in Table 3. These values were selected based on the results of triaxial tests performed prior to true triaxial tests in order to obtain the maximum strength and other mechanical parameters of the Carynginia shale samples. Few examples of the stress-strain curves obtained from TTSC tests on the shale samples are shown in Figure 17.

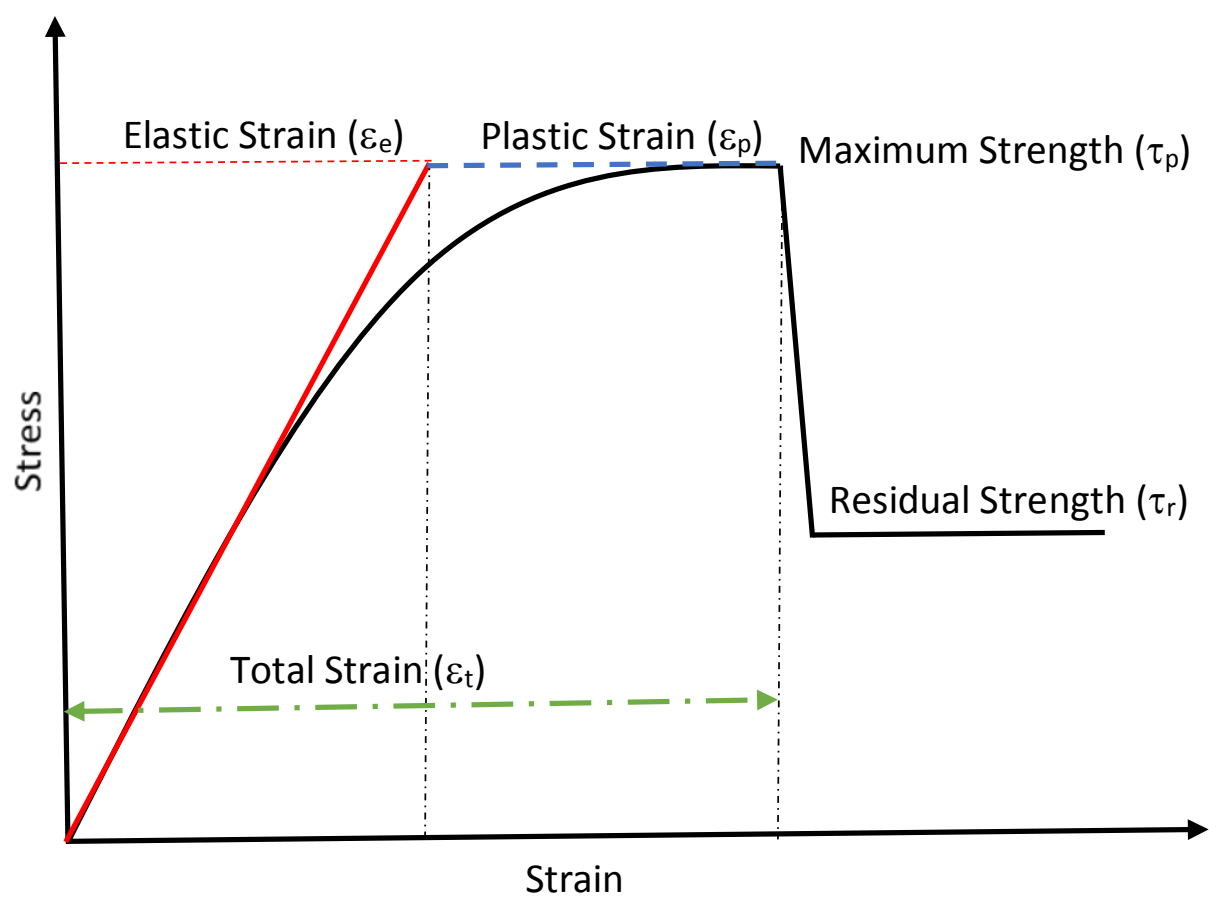

Figure 16: A generic stress-strain curve showing how parameters included in $\mathrm{Bl}_{4}$ and $\mathrm{Bl}_{5}$ can be estimated (modified after Holt et al., 2011)

As seen in curves shown in Figure 17, the Carynginia shale is demonstrating a complete brittle failure under different stress states. Generally, samples were quite strong considering the fact 
that the confining pressure was increasing the resistance, although the effect of measurements perpendicular to the bedding plane should not be neglected. Figure 18 displays the images of few cube samples tested under different stress states.

From Figure 17, it is noticed that the failure development in the shale samples is gradual and associated with multiple failure planes during the failure propagation. These characteristics are, in fact, the essential parts of the analysis for brittleness estimations, but are not completely caught by any of the approaches defined earlier for experimental tests based determinations of brittleness.

a)

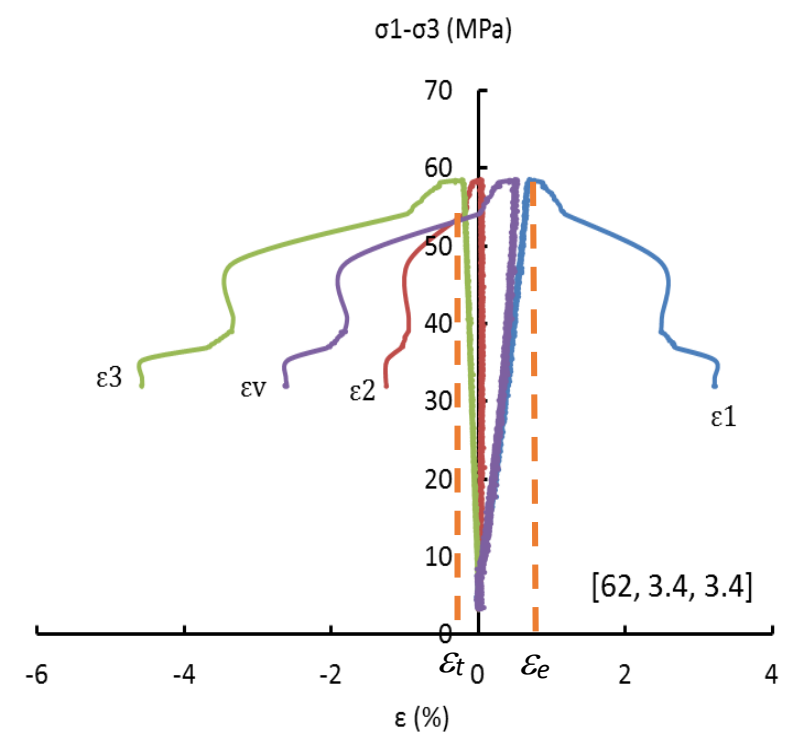

c)

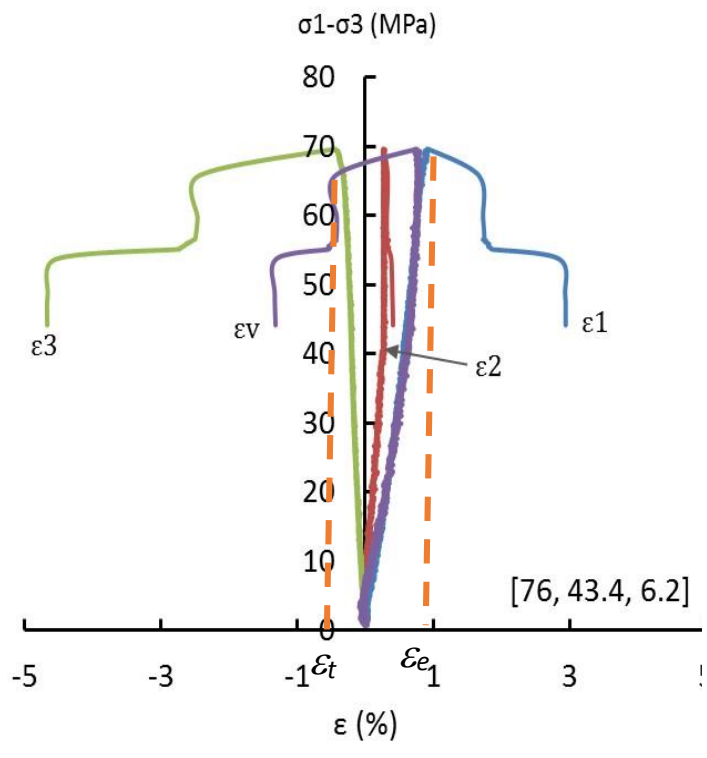

b)

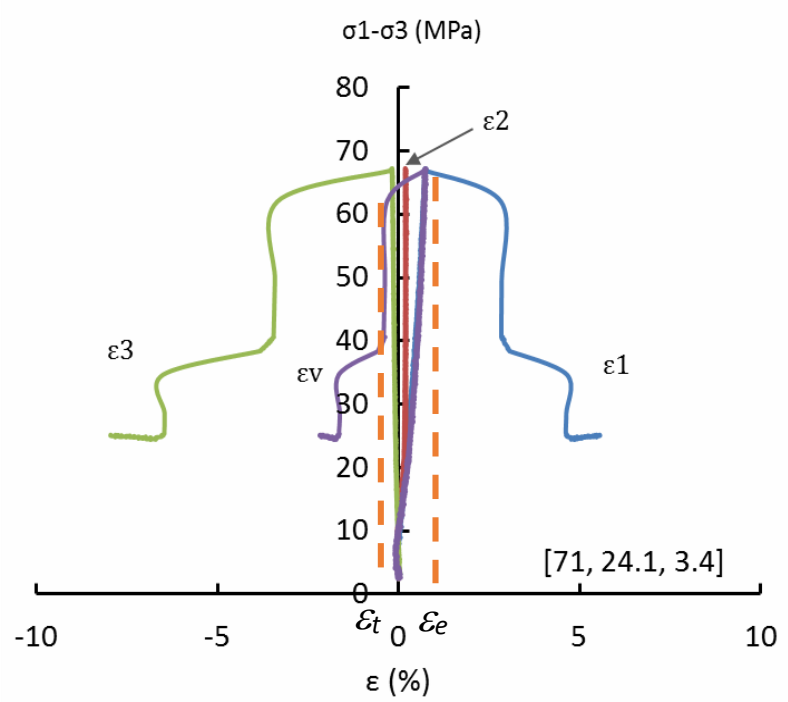

d)

$$
\sigma 1-\sigma 3(\mathrm{MPa})
$$

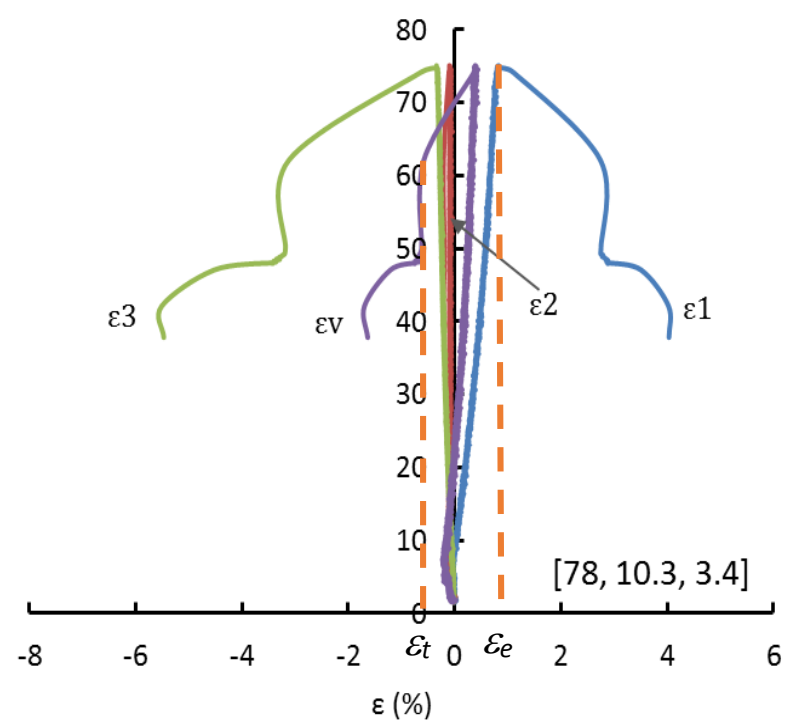

Figure 17: Stress-strain plots obtained from performing the true triaxial tests on the Carynginia 
shale. Values in brackets are $\sigma_{1}, \sigma_{2}, \sigma_{3}$ respectively in MPa. Dashed lines are showing the elastic and total strains

Attempting to estimate brittleness based on the true triaxial tests, it was found that the results obtained from $\mathrm{Bl}_{4}$ are not reliable due to its dependency on the stiffness of the apparatus and the procedure of the test. In addition, the BI could have increased if the samples had been left for a long time after reaching the post state failure. Therefore, for the purpose of this study, $\mathrm{Bl}_{5}$ was exclusively used to estimate brittleness based on the plastic strains.

The results obtained revealed that the $\mathrm{BI}$ varies from $60 \%$ to $85 \%$ depending on the differential stress applied during the tests in horizontal directions (i.e., intermediate and least stress directions). Although, none of the samples revealed any ductile behaviours initially as they have been apparently taken from the lower (brittle) part of the Carynginia shale, it was found that as the difference between stresses in the horizontal directions increases, the tendency to show ductile behaviour increases. However, this tendency suddenly drops when the ratio of horizontal stresses become very high.

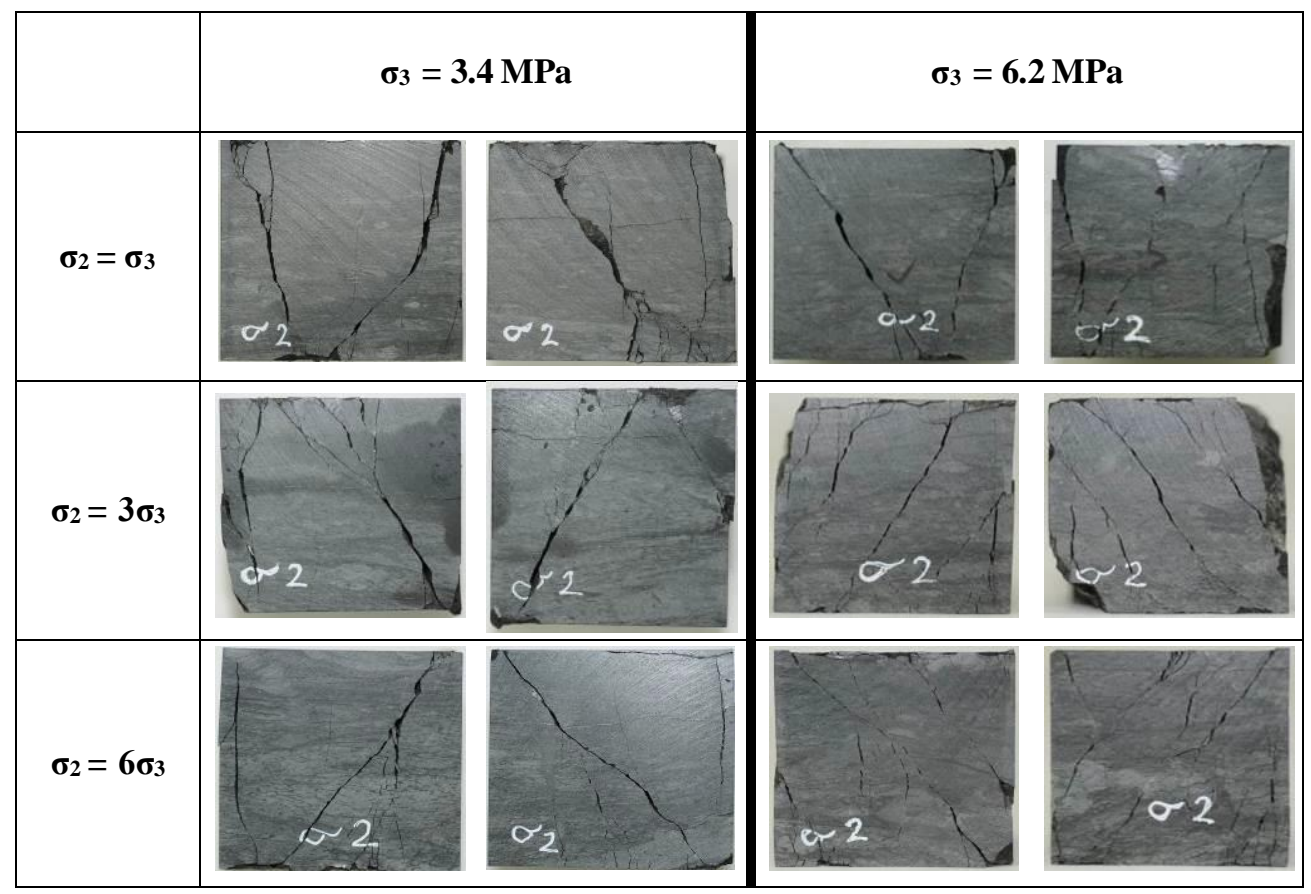

Figure 18: Carynginia shale samples after the true triaxial tests. The directions of principal stresses are as same as those shown in Figure 12 (left).

However, due to complicated stress states in the true triaxial tests, observation of transition from brittle into ductile behaviour and vice versa was not an easy and more studies with more samples are still required to get an ultimate conclusion. 


\section{Discussion}

There have been many approaches developed and used for estimation of brittleness, although the number of studies carried out on shale gas formations are very limited. There are few points about this kind of estimation which need precaution when interpreting the results. These points are as follows:

- Carbonates may not be the representative of brittleness in gas shale formation and a carefully analysis should be performed before using any approach to estimate brittleness. The cross-plot of shear versus lame modulus might be useful in this case to find the dominant minerals contributing into brittleness.

- While saturating gas shale samples, cautions should be taken to prevent loss of water in the pore space which may results in wrong interpretation due to increase of strength and stiffness of samples.

- More studied are still required to detect the transition taking place from elasticity to plasticity during mechanical testing. This can probably be done by unload-reload curves assessments, but require more attentions.

- Brittleness depends on the stress anisotropy when it comes to true triaxial testing. Complicated changes might be observed in the variation of strength and elastic parameters during these tests. These changes can subsequently be reflected on the BI estimation. Thus a careful analysis of changes induced due to stress anisotropy should be conducted before estimation of shale gas brittleness.

- The estimation provided using different approaches may not be the same due to the assumptions included in any of them. However, big discrepancies in the results should not be neglected.

\section{Conclusions}

An accurate estimation of brittleness is crucial for having a successful fracture initiation and propagation in gas shale reservoirs. Three different approaches were used in this paper to determine the brittleness of the Carynginia shale formation. The results obtained indicated that the lower part of the shale formation has the potential of having a network of fractures due to a high brittleness index, although a careful analysis of TOC might be required. However, estimations provided for brittleness using the well logs, mineralogical reports and experimental tests based data analysis were not the same due to the assumptions involved in their principles. In fact, the log data analysis gives a BI of approximately $60 \%$ for the Carynginia while that of the mineralogical data analysis was around $70 \%$. The $\mathrm{Bl}$ obtained from running the true triaxial test, however, varies from $60 \%$ to $85 \%$ due to the usage of different stress states. Therefore, an average brittleness of $65 \%$ can be considered for the lower part of the Carynginia formation. It was also found that the $G-\lambda$ cross-plot is able to provide a useful space in which dominant 
minerals contributing into brittleness can be caught without having a detailed mineralogy report. The results of the geomechanical tests using the TTSC also revealed that there is a complicated link between the differential horizontal stress and brittleness which requires more studies.

\section{Acknowledgment}

Authors would like to express their appreciation to Senergy Company for providing the Interactive Petrophysics (IP) tool.

\section{References}

Altindag, R. 2003. Correlation of Specific Energy with Rock Brittleness Concepts on Rock Cutting. J. South African Institute of Mining and Metallurgy 103 (3): 163-171.

Altindag, R., 2010. Assessment of some brittleness indexes in rock-drilling efficiency. Rock Mech. Rock Eng. 43, 361-370

Andreev, G.E. 1995. Brittle Failure of Rock Materials: Test Results and Constitutive Models, Taylor \& Francis.

Aplin, A.C., Fleet, A.J., Mac Quaker, J.H.S., 1999. Muds and Mudstones: Physical and Fluid Flow Properties. In: Geological Society of London, Special Publication, vol. 158, p. 190-199

AWE. 2011, Woodada Deep, 01 Well Completion Report. Western Australia.

Bang, J., Solstad, A., Mjaaland, S., 2000. Formation electrical anisotropy derived from induction log measurements in a horizontal well. SPE 2000. Annual Technical Conference and Exhibition, Formation Evaluation and Reservoir Geology, Dallas, Texas, USA

Berryman, J. G., P. A. Berge, and B. P. Bonner, 1999, Role of $\lambda$-diagrams in estimating porosity and saturation from seismic velocities: 69th Annual International Meeting, SEG, Expanded Abstracts, 176-179.

Berryman, J. G., P. A. Berge, and B. P. Bonner, 2002, Estimating rock porosity and fluid saturation using only seismic velocities: Geophysics, 67, 391-404, doi: 10 .1190/1.1468599.

Bishop, A.W. 1967. Progressive failure with special reference to the mechanism causing it. Proc. Geotechnical Conference, Oslo, Norway. 2: 142-150

Chen, J., Xiao, X., 2013. Mineral composition and brittleness of three sets of Paleozoic organicrich shales in China South area. J. China Coal Soc. 38 (5), 822-826.

Davis, D., and S. J. Reynolds, 1996, Structural geology of rocks and regions, 2nd ed.: Wiley

Delle Piane, C., Dewhurst, D.N., Siggins, A.F., Raven, M.D., 2011. Stress-induced anisotropy in Brine saturated shale. Geophys. J. Int. 184 (2), 897-906

Detournay, E., Sarout, J., Tan, C., Caurel, J., 2006. Chemoporoelastic parameter identification of a reactive shale. In: Huyghe, J.M., Raats, P.A.C., Cowin, S.C. (Eds.), Symposium on Mechanics of Physicochemical and Electrochemical Interactions in Porous Media. International Union of Theoretical and Applied Mechanics. Springer, Berlin 
Dewhurst, D.N., Hennig, A., 2003. Geomechanical properties related to top seal leakage in the Carnarvon Basin, Northwest Shelf, Australia. Pet. Geosci. 9, 255-263.

Dewhurst, D.N., Sarout, J., Delle Piane, C., Siggins, A. F., Raven, M. D. 2015, Empirical strength prediction for preserved shales, Mar Petrol Geol, 67, 512-525

Dewhurst, D.N., Siggins, A.F., Kuila, U., Clennell, M.B., Raven, M.D., Nordgård- Bolås, H.M., 2008. Rock physics, geomechanics and rock properties in shales: where are the links? In: Proceedings of the 1st SHIRMS Conference, Perth, p. 14.

Fjaer, E., Holt, R.M., Hordrud, P., Raaen, A.M., Risnes, R., 2008. Petroleum related rock Rock Mechanic, Developments in Petroleum Science, Elsevier.

Geng Z., Chen M., Jin Y., Du X.Y., Yang S., Li D.D. and Fang X. 2015, Brittleness Determination of Rock Using Rock Physics Techniques Calibrated with Macro Damage, 49th US Rock Mechanics/Geomechanics Symposium held in San Francisco, CA, USA, 28 June, ARMA 15-268

Gholami, R., Rabie, M., Rasouli, V. Aadnoy, B., 2015. Application of quantitate risk assessment in wellbore stability analysis, J Petrol Sci. Eng. 135, 185-200

Gholami, R., Rasouli. V. 2014. Mechanical and Elastic Properties of Transversely Isotropic Slate, Rock Mechanics Rock Engineering, 47 (5), 1763-1773, DOI 10.1007/s00603-013-0488-2.

Ghorbani, A., Zamora, M., Cosenza, P., 2009. Effects of desiccation on the elastic wave velocities of clay-rocks. Int. J. Rock Mech. Min. Sci. 46 (8), 1267-1272.

Goktan, R.M., Yilmaz, N.G., 2005. A new methodology for the analysis of the relationship between rock brittleness index and drag pick cutting. J. South Afr. Inst. Min. Metall. 105, 727-733.

Goodway, B., J. Varsek, and C. Abaco, 2006, Practical applications of P-wave AVO for unconventional gas resource plays - I: Seismic Petrophysics and isotropic AVO: CSEG Recorder, 31, 90-95.

Goodway, B., M. Perez, J. Varsek, and C. Abaco, 2010, Seismic Petrophysics and isotropicanisotropic AVO methods for unconventional gas exploration: The Leading Edge, 29, 936-944

Goodway, B., T. Chen, and J. Downton, 1997, Improved AVO fluid detection and lithology discrimination using Lamé parameters $\lambda \rho, \mu \rho$ and $\lambda \mu$ fluid stack from $\mathrm{P}$ - and Sinversion: 67 th Annual International Meeting, SEG, Expanded Abstracts, 183-186.

Gorter, J.D., Hearty, D.J., Bond, A.J., 2004-Jurassic petroleum systems in the Houtman Subbasin, northwestern offshore Perth Basin, Western Australia: a frontier petroleum province on the doorstep? The APPEA Journal, 44(1), 13-57.

Guo, T., Zhang, S., Ge, H., Wang, X., Lei, X., Xiao, B., 2015. A new method for evaluation of fracture network formation capacity of rock. Fuel, 140, 778-787.

Hajiabdolmajid, V. and Kaiser, P. 2003. Brittleness of Rock and Stability Assessment in Hard-Rock Tunneling. Tunneling and Underground Space Technology 18 (1): 35-48.

Handin, J., and R. V. Hager, 1958, Experimental deformation of sedimentary rocks under confining pressure: Tests at high temperature on dry samples: AAPG Bulletin, 42, 2892-2934 
Hetenyi M (1966). Handbook of experimental stress analysis. John Wiley, New York, p.15

Holt, R.M., Fjær, E., Stenebråten, J.F., Magnar Nes, O. 2015. Brittleness of shales: Relevance to borehole collapse and hydraulic fracturing, J Petrol Sci Eng, 131, 200-209

Hucka V, Das B, 1974. Brittleness determination of rocks by different methods. Int. J. Rock. Mech. Min. Sci. Geomech. Abstr.,11: 389-392.

Jaeger, J.C., Cook, N.G.W., Zimmerman, R. W., 2007. Fundamentals of Rock Mechanics, fourth ed. Blackwell Publ. p. 500.

Jarvie, D.M., Hill, R.J., Ruble, T.E., Pollastro, R.M., 2007. Unconventional shale-gas systems: The Mississippian Barnett Shale of north-central Texas as one model for thermogenic shale-gas assessment. AAPG Bull. 91 (4), 75-499.

Jin, X., Shah, S. N., Roegiers, J. C. 2015, An Integrated Petrophysics and Geomechanics Approach for Fracability Evaluation in Shale Reservoirs, SPE Hydraulic Fracturing Technology Conference, The Woodlands, Texas, USA, 4-6 February, SPE 168589

Katsube, T.J., Mudford, B.S., Best, M.E., 1991. Petrophysical characteristics of shales from the Scotian shelf. Geophysics, 56, 1681-1689.

Kias, E., Maharidge, R., Hurt, R. 2015. Mechanical Versus Mineralogical Brittleness Indices Across Various Shale Plays, SPE Annual Technical Conference and Exhibition held in Houston, Texas, USA, 28-30 September 2015, SPE-174781-MS

Lawn, B. and Marshall, D. 1979. Hardness, Toughness, and Brittleness: An Indentation Analysis. J. American Ceramic Society, 62 (7-8), 347-350

Ma, X., Haimson, B. 2013. Failure characteristics of a quartz-rich, high-porosity sandstone subjected to true triaxial testing. 47th US Rock Mechanics/Geomechanics Symposium. San Francisco, CA, USA.

Meng, F., Zhou, H., Zhang, C., Xu, R., Lu, J., 2014. Evaluation methodology of brittleness of rock based on post-peak stress-strain curves. Rock Mech. Rock Eng. 48(5), 1787-1805

Mogi, K. 1971. Fracture and flow of rocks under high triaxial compression. Journal of Geophysical Research, 76, 1255-1269.

Morley A, 1944, Strength of materials. Longman. Green, London, p.35.

Naumann, M., Hunsche, U., Schulze, O. 2007. Experimental investigations on anisotropy in dilatancy, failure and creep of Opalinus Clay. Phys Chem Earth, Parts A/B/C, 32, 889-895

Norwest-Energy. 2011. Integrated tight rock analysis shale gas Australia Arrowsmith-2 well. TerraTek

Nygard, R., Gutierrez, M., Gautam, R., Høeg, K., 2004a. Compaction behavior of argillaceous sediments as function of diagenesis. Mar. Pet. Geol. 21, 349-362.

Obert L, Duvall WI, 1967. Rock mechanics and the design of fractures in rock. John Wiley, New York, p. 278.

Perez, M., 2011, Developing templates for integrating quantitative geophysics and hydraulic 
fracture completions data: Part I - Principles and theory: 81st Annual International Meeting, SEG, Expanded Abstracts, 1794-1798

Perez, R., Marfurt, K. 2014. Mineralogy-based brittleness prediction from surface seismic data: Application to the Barnett Shale, Interpretation, 2 (4), T255-T271

Playford, P. E., Cockbain, A. E. \& low, G. H., 1976, Geology of the Perth Basin Western Australia. Geological Survey of Western Australia, Bulletin, 124

Popp, T., Salzer, K. 2007. Anisotropy of seismic and mechanical properties of Opalinus clay during triaxial deformation in a multi-anvil apparatus. Phys Chem Earth, Parts $A / B / C, 32,879-888$

Protodyakonov, M. 1962. Mechanical Properties and Drillability of Rocks. Proc., the 5th Symposium on Rock Mechanics, Minnesota, May

Ramsey JG, 1967, Folding and Fracturing of Rocks. McGraw-Hill, London, p. 289

Rasouli, V., Evans, J. B. 2010. A True Triaxial Stress Cell (TTSC) to simulate deep downhole drilling conditions. APPEA journal, 50, 61-70.

Rickman, R., Mullen, M.J., Petre, J.E., Grieser, B., Kundert, D., 2008. A practical use of shale Petrophysics for stimulation design optimization: all shale plays are not clones of the Barnett Shale. In: SPE Annual Technical Conference and Exhibition. Society of Petroleum Engineers.

Sarmadivaleh, M. 2012. Experimental and Numerical Study of Interaction of a Pre-Existing Natural Interface and an Induced Hydraulic Fracture, PhD thesis, Curtin University

Sarout, J., Detournay, E., 2011. Chemoporoelastic analysis and experimental validation of the pore pressure transmission tests for reactive shales. Int. J. Rock Mech. Min. Sc. 48 (5), 759772.

Selley RC. UK shale gas: the story so far. Mar. Petroleum Geol, 31(1): 100-109.

Sehgal, J., Nakao, Y., Takahashi, H. et al. 1995. Brittleness of Glasses by Indentation. J. Materials Science Letters 14 (3): 167-169. http:// dx.doi.org/10.1007/BF00318244.

Simon, Y., 2005, Stress and fracture characterization in a shale reservoir, North Texas, using correlation between new seismic attributes and well data: M.S. thesis, Department of Geosciences, University of Houston

Singh, P., 2008, Lithofacies and sequence stratigraphic framework of the Barnett Shale: Ph.D. dissertation, ConocoPhillips School of Geology and Geophysics: The University of Oklahoma.

Sone, H., Zoback, M. D. 2013. Mechanical properties of shale-gas reservoir rocks - Part 2: Ductile creep, brittle strength, and their relation to the elastic modulus. Geophysics, 78, 5-10.

Sondergeld, C.H., Newsham, K.E., Comisky, J.T., 2010. Petrophysical considerations in evaluating and producing shale gas resources. In: SPE Unconventional Gas Conference. Society of Petroleum Engineers.

Song, T., Cawood, P.A., 2000. Structural styles in the Perth Basin associated with Mesozoic breakup of Greater India and Australia. Tectonophysics, 317, 55-72.

Stjern, G., Agle, A., Horsrud, P., 2003. Local rock mechanical knowledge improves drilling 
performance in fractured formations at the Heidrun field. J. Pet. Sci. Eng. 38, 83-96

Wang, D., Ge, H., Wang, X., Wang, J., Meng, F., Suo, Y., Han, P., 2015. A novel experimental approach for Fracability evaluation in tight-gas reservoirs. J. Nat. Gas Sci. Eng. 23, 239-249.

Wang, F. P., Gale J. F. W., 2009, Screening criteria for shale-gas systems: Gulf Coast Association of Geological Societies Transactions, 59, 779-793

Wawersik, W. R., Carlson, L. W., Holcomb, D. J., Williams, R. J. 1997. New method for true-triaxial rock testing. Inter J Rock Mech Min Sci, 34, 3301-33014.

Wei, Y., 2003. Determining resistivity anisotropy of geological formation by joint inversion of lateral and induction logs. Seismol. Geol. 25 (2), 274-279.

Yagiz, S. 2009. Assessment of Brittleness Using Rock Strength and Density with Punch Penetration Test. Tunnel Underg Space Technol, 24 (1): 66-74. http://dx.doi.org/10.1016/j.tust.2008.04. 002.

Yang, L., Ge, H., Shen, Y., Zhang, J., Yan, W., Wu, S., Tang, X., 2015. Imbibition inducing tensile fractures and its influence on in-situ stress analyses: a case study of shale gas drilling. J. Nat. Gas Sci. Eng. 26, 927-939.

Yang, Y., Aplin, A.C., 2007. Permeability and petrophysical properties of 30 natural mudstones. J. Geophys. Res. 112, B03206, doi:1029/2005JB004243.

Yang, Y., Sone, H., Hows, A., Zoback, M. D. 2013. Comparison of Brittleness Indices in Organicrich Shale Formations. Proceedings of $47^{\text {th }}$ U.S. Rock Mechanics/Geomechanics Symposium, San Francisco, CA.

Yi., Y., Hiroki, S., Amie, H., Zoback, M.D. 2013. Comparison of Brittleness Indices in Organic-rich Shale Formations, 47 US Rock Mechanics / Geomechanics Symposium held in San Francisco, CA, USA, ARMA 13-403.

Young, Hamish, and Anonymous. 2006, Chronostratigraphy of the Late Permian Dongara Sandstone, Northern Perth Basin. American Association of Petroleum Geologists International Conference Abstracts.

Yuan, J., Deng, J., Zhang, D., Li, D., Yan, W., Chen, C., Cheng, L., Chen, Z., 2014. Fracability evaluation of shale-gas reservoirs. Acta Pet. Sin. 34 (3), 523-527

Zoback, M. 2007. Reservoir Geomechanics, Cambridge University Press. 506 p 